\title{
PENGARUH PELATIHAN SUMBER DAYA INSANI TERHADAP KINERJA KARYAWAN BMT-UGT SIDOGIRI DI SURABAYA DAN SIDOARJO
}

\author{
Azizah Nur Rahmayani \\ Mahasiswa Program Studi S-1 Ekonomi Islam - Fakultas Ekonomi dan Bisnis - Universitas \\ Airlangga \\ Ari Prasetya \\ Departemen Ekonomi Syariah - Fakultas Ekonomi dan Bisnis - Universitas Airlangga \\ Email: ariffeunair@yahoo.co.id
}

\begin{abstract}
The purposes of employees training are to improve, develop, and enhance their skills. In an organization, the scoring of employees' performance has very essential role in making decision effectively related to the whole process of human resource management. This research purposes to reveal how far the training influences the performance of employees of BMT Sidogiri in Surabaya and Sidoarjo

This research used quantitative approach with saturated sampling method (a technique of sampling if the entire member of population is used). Consequently it is called census research. It investigates 34 employees who work as account officer. Data collected with questionnaires and analyzed with multiple linier regression.

The result of this research shows the human resource training variable simultaneously and reliably can influence the employees' performance based on the result of $F$ test is 65,390 with significance level is 0,000 . The contribution of human resource training is $92.1 \%$ with the rest is the other variables. Partially, all human resource variable influences to the employees' performance according to t test result (the each level of training instructor variable, training participants variable, training method, training material, and training facility is less than 0,05 ). Training facility is the dominant variable regards to the employees' performance with 0,374 beta level.

Keywords: Human Resource Training, Training Instructor, Training Participants, Training Material, Training Method, Training Facility.

\section{PENDAHULUAN}

\section{A. Latar Belakang}

Lembaga keuangan dituntut untuk mampu menyesuaikan dengan situasi dan kondisi saat ini, dan semua itu dapat dilakukan oleh organisasi yang didukung oleh kualitas sumber daya insani yang memadai. Firman Allah dalam surat Yusuf ayat 55 :

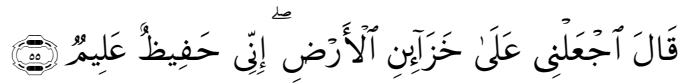

Qālaj 'alnī 'alā khazā'inil arḍ, innī ḥafižun 'alimu

Artinya : Berkata Yusuf: "Jadikanlah aku bendaharawan negara (Mesir); Sesungguhnya aku adalah orang yang pandai menjaga, lagi berpengetahuan". (DEPAG RI, Al-Qur'an QS. Yusuf ayat 55)

Berkaitan dengan penjelasan
diatas, dapat ditarik kesimpulan
bahwasannya seorang karyawan
lembaga keuangan diharapkan memiliki
kepandaian dalam menjaga harta dan
amanah yang dititipkan kepadanya.
Selain itu, karyawan lembaga keuangan
seharusnya memilik pengetahuan yang
\end{abstract}


mendalam terkait lembaga keuangan khususnya yang berbasis syariah

Pelatihan membantu karyawan dalam memahami suatu pengetahuan praktis dan penerapannya, guna meningkatkan ketrampilan, kecakapan, dan sikap yang diperlukan oleh organisasi dalam mencapai tujuan yang diinginkan. Seperti sebagaimana Firman Allah dalam surat Al-Qashas ayat 26 :

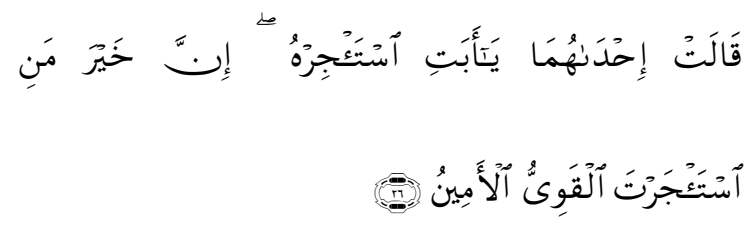

Qālat iḥdāhumā yā abatis ta'jirhu inna khaira manis ta'jartal qawiyyul amin

Artinya : Salah seorang dari kedua wanita itu berkata: "Ya bapakku ambillah ia sebagai orang yang bekerja (pada kita), karena Sesungguhnya orang yang paling baik yang kamu ambil untuk bekerja (pada kita) ialah orang yang kuat lagi dapat dipercaya". (DEPAG Rl, Al-Qur'an QS. Al-Qashas ayat 26)

Berkaitan dengan ayat diatas jelas bahwasannya seorang karyawan dipilih berdasarkan kekuatan mental dan fisik dalam menghadapi tugas pekerjaan yang dibebankan kepadanya serta dapat dipercaya. Kekuatan yang seperti itu dapat dihasilkan melalui pelatihan yang secara teratur diberikan kepada karyawan guna memperbaiki kinerjanya. Permitasari (2012) mengatakan pelatihan yang efektif secara signifikan berpengaruh terhadap peningkatan proses kerja yang luar biasa pesatnya.

Dalam PP RI nomor 31 Tahun 2006 Bab I pasal I ayat 1 yang dinyatakan "Pelatihan kerja adalah keseluruhan kegiatan untuk memberi, memperoleh, meningkatkan, serta mengembangkan kompetensi kerja, produktivitas, disiplin, sikap, dan etos kerja pada tingkat keterampilan dan keahlian tertentu sesuai dengan jenjang dan kualifikasi jabatan atau pekerjaan." Dalam PP RI nomor 31 Tahun 2006 Bab VI pasal 13 ayat 1 yang dinyatakan "Setiap tenaga kerja mempunyai kesempatan untuk mengikuti pelatihan kerja sesuai dengan bakat, minat, dan kemampuannya."

Untuk bidang lembaga keuangan mikro syariah khususnya BMT, aturan pelaksanaannya terdapat dalam Undang-Undang Republik Indonesia Nomor 17 Tahun 2012 tentang Perkoperasian pasal 6 ayat 1 butir (e) yang menyatakan : "Koperasi menyelenggarakan pendidikan dan pelatihan bagi Anggota, Pengawas, Pengurus, dan karyawannya, serta memberikan informasi kepada masyarakat tentang jati diri, kegiatan, dan kemanfaatan Koperasi."

Salah satu lembaga keuangan Islam non bank adalah Baitul Maal wat Tamwil (BMT) yang berorientasi pada masyarakat Islam lapisan bawah. 
Kehadiran BMT muncul disaat ummat Islam mengharapkan adanya lembaga keuangan yang menggunakan prinsipprinsip syari ah dan bebas dari unsur riba' yang diasumsikan haram (Ridwan, 2004:47). BMT UGT Sidogiri telah lama berdiri dijagat keuangan mikro syariah, namun tidak memungkiri bahwa sumber daya insani yang ada juga memerlukan pemeliharaan dan terus diasah untuk perbaikan kinerjanya dalam melayani nasabah.

\section{B. Rumusan Masalah}

Berdasarkan latar belakang diatas, peneliti mengambil

rumusan permasalahan, yakni :

1. Apakah pelatihan sumber daya insani yang terdiri dari instruktur, peserta, materi, metode dan sarana pelatihan secara simultan (bersama-sama) memiliki pengaruh yang signifikan terhadap kinerja karyawan BMT UGT Sidogiri di Surabaya dan Sidoarjo?

2. Apakah pelatihan sumber daya insani yang terdiri dari instruktur, peserta, materi, metode dan sarana pelatihan secara parsial (terpisah) memiliki pengaruh yang signifikan terhadap kinerja karyawan BMT UGT Sidogiri di Surabaya dan Sidoarjo?

3. Manakah pelatihan sumber daya insani yang terdiri dari instruktur, peserta, materi, metode dan sarana pelatihan yang memiliki pengaruh dominan terhadap kinerja karyawan BMT UGT Sidogiri di Surabaya dan Sidoarjo?

\section{Tujuan Penelitian}

Berdasarkan rumusan masalah diatas, maka tujuan dari penelitian ini adalah :

1. Untuk mengetahui besarnya pengaruh pelatihan sumber daya insani yang terdiri dari instruktur, peserta, materi, metode dan sarana pelatihan secara simultan terhadap kinerja karyawan BMT UGT Sidogiri di Surabaya dan Sidoarjo.

2. Untuk mengetahui besarnya pengaruh pelatihan sumber daya insani yang terdiri dari instruktur, peserta, materi, metode dan sarana pelatihan secara parsial terhadap kinerja karyawan BMT UGT Sidogiri di Surabaya dan Sidoarjo.

3. Untuk mengetahui pengaruh pelatihan sumber daya insani yang terdiri dari instruktur, peserta, materi, metode dan sarana pelatihan yang dominan terhadap kinerja karyawan BMT UGT Sidogiri di Surabaya dan Sidoarjo.

II. LANDASAN TEORI DAN PENGEMBANGAN HIPOTESIS

\section{A. Sumber Daya Insani}

Werther dan Davis (dalam Sutrisno, 2010 : 4) menyatakan bahwa :

Sumber daya insani adalah pegawai yang siap, mampu, dan siaga dalam mencapai tujuan-tujuan organisasi. Sebagaimana dikemukakan bahwa dimensi pokok sumber daya adalah kontribusinya terhadap organisasi , sedangkan dimensi pokok insani adalah perlakuan kontribusi terhadapnya yang akan menentukan kualitas dan kuantitas hidupnya.

\section{B. Pelatihan}


Pelatihan didefinisikan oleh Ivancevich (dalam Sutrisno, 2010 : 67) sebagai :

Usaha untuk meningkatkan kinerja karyawan dalam pekerjaannya sekarang atau dalam pekerjaan lain yang akan dijabatnya segera. Pelatihan terkait dengan ketrampilan dan kemampuan yang diperlukan untuk pekerjaan yang sekarang dilakukan. Pelatihan berorientasi ke masa sekarang dan membantu karyawan untuk menguasai keterampilan dalam pekerjaannya.

Menurut Moekijat (1991:38) pada dasarnya tujuan umum dari pelaksanaan pelatihan adalah :

1. Untuk mengembangkan keahlian, sehingga pekerjaan dapat diselesaikan dengan lebih cepat dan efektif.

2. Untuk mengembangkan pengetahuan, sehingga pekerjaan dapat diselesaikan secara rasional, dan

3. Untuk mengembangkan sikap,sehingga menimbulkan kemavan kerjasama dengan teman-teman pegawai dan manajemen (pimpinan).

Beberapa manfaat yang diperoleh dari pelatihan menurut Sutrisno (2010: 69), antara lain:

1. Meningkatkan produktifitas kerja.

2. Meningkatkan mutu kerja.

3. Meningkatkan ketepatan dalam perencanaan SDM.

4. Meningkatkan moral kerja.
5. Menjaga kesehatan dan keselamatan.

6. Menunjang pertumbuhan pribadi. Menurut Rivai (2010 : 217-219) manfaat pelatihan dapat dikategorikan untuk karyawan, perusahaan dan hubungan sumber daya insani , intra, antargrup dan pelaksanaan kebijakan.

Secara sederhana, tahapan dasar pelatihan mempunyai lima langkah menurut Panggabean (2002 : 42) dijelaskan dalam gambar berikut :

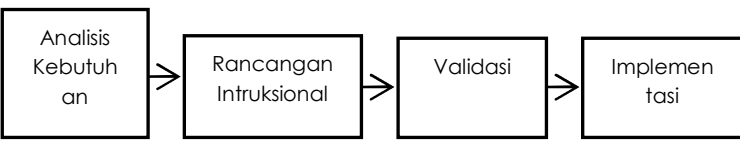

Pada dasarnya metode pelatihan dapat dikelompokkan ke dalam dua kelompok sebagaimana dijelaskan oleh Panggabean (2002: 45), yaitu :

1. On the job training meliputi program magang, rotasi pekerjaan dan understudy atau coaching.

2. Off the job training meliputi ceramah kelas, presentasi video, pelatihan vestibule, belajar mandiri, praktik laboratorium, pelatihan tindakan, role playing, behaviour modeling.

\section{Menurut Hasibuan (2005:75-76)} dalam melaksanakan pelatihan ini ada beberapa faktor yang berperan dalam keberhasilan pelatihan. Efektivitas pelatihan dipengaruhi oleh beberapa faktor, diantaranya :

1. Instruktur

Instruktur atau pelatih yaitu seseorang atau tim yang memberikan pelatihan kepada karyawan guna memperoleh pengetahuan, keterampilan, dan sikap 
yang diperlukan sesuai dengan sasaran yang diinginkan perusahaan. Instruktur memiliki peranan penting terhadap kemajuan kemampuan para karyawan yang akan dikembangkan. Instruktur hendaknya memiliki syarat yakni kemampuan untuk menguasai materi yang akan diberikan dalam pelatihan dengan baik. Menyampaikan materi sesuai dengan tingkat pemahaman peserta, kemampuan berkomunikasi dengan peserta secara baik, mampu mendorong peserta untuk aktif terlibat dan kemampuan bersosialisasi dengan bersedia memberikan bantuan saat pelatihan berlangsung.

\section{Peserta}

Menetapkan syarat-syarat dan jumlah peserta yang dapat mengikuti pelatihan. Menurut Hardjana (2001:23) beberapa syarat yang sebaiknya dipenuhi peserta yakni peserta berminat untuk maju dan berkembang, peserta bersemangat dan antusias dalam mengikuti pelatihan, peserta ikut aktif dan berpartisipasi dalam pelatihan dan menerima materi pelatihan dengan baik.

\section{Materi Pelatihan}

Materi pelatihan ditentukan oleh tujuan yang harus dicapai sehingga penetapannya harus sistematis. Apakah materi pelatihan sesuai dengan tingkat kebutuhan pekerjaan peserta, peserta dapat memahami materi pelatihan yang diberikan, materi pelatihan berupa buku, modul, kertas kerja membantu peserta pelatihan belajar, materi pelatihan yang selama ini diberikan dapat diterapkan dalam pekerjaan.

\section{Metode Pelatihan}

Agar tercapai efektivitas dan efisiensi pelatihan, maka metode pelatihan harus berorientasi pada kebutuhan pekerjaan tergantung media, peralatan serta metode pelatihan yang digunakan itu sendiri.

5. Sarana Pelatihan

Mempersiapkan tempat dan alat-alat yang akan digunakan dalam pelaksanaan pelatihan. Penentuan lingkungan pelaksanaan program perlu dipertimbangkan untuk mengetahui apakah tempat pelaksanaan nyaman bagi peserta, fasilitas yang mendukung pelatihan serta jarak tempun dan waktu pelatihan tidak mengganggu jadwal pekerjaan karyawan.

\section{Kinerja}

Permitasari (2012) mengatakan kinerja sumber daya insani merupakan istilah yang berasal dari kata job performance atau actual performance (prestasi kerja atau prestasi sesungguhnya yang dicapai seseorang).

Definisi kinerja karyawan menurut Mangkunegara (2000:67) bahwa kinerja karyawan (prestasi kerja) adalah hasil kerja secara kualitas dan kuantitas yang dicapai seorang karyawan dalam melaksanakan tugasnya sesuai dengan tanggung jawab yang diberikan kepadanya.

Berkaitan erat dengan kinerja karyawan BMT UGT Sidogiri di dalam melaksanakan tugasnya sehari-hari 
sehingga dalam melaksanakan tugasnya, karyawan BMT UGT Sidogiri menerapkan manajemen rasul yakni shiddiq/jujur, tabligh/komunikatif, amanah/dapat dipercaya dan fathonah/profesional.

Karyawan BMT UGT Sidogiri memiliki job desk masing-masing sesuai dengan fungsi dan kewenangan jabatannya. Dalam penelitian ini, karyawan yang menjadi responden adalah karyawan bagian account officer.

Dalam kaitannya dengan karyawan, Gomes (2000:142) mengemukakan ukuran-ukuran kinerja karyawan dapat diukur dengan indikator meliputi elemen, yaitu :

1. Quantity of work : yaitu jumlah hasil kerja yang didapat dalam suatu periode waktu yang ditentukan. Berdasarkan Job Description Karyawan Koperasi BMT - UGT Sidogiri bagian kepala cabang pembantu, jumlah hasil kerja adalah pencapaian target sesuai dengan proyeksi yang telah dibuat dan ditetapkan di masingmasing cabang BMT-UGT Sidogiri.

2. Quality of work : yaitu kualitas kerja yang dicapai berdasarkan syaratsyarat kesesuaian dan kesiapannya. Berdasarkan Job Description Karyawan Koperasi BMT - UGT Sidogiri bagian account officer (AO) poin 8 menyatakan bahwa $A O$ bertanggung jawab terhadap penagihan pembiayaan dan mengawal kelancaran setoran tagihan angsuran pembiayaan dengan selalu memonitoring calon anggota/anggota peminjam.

3. Job knowledge : luangnya pengetahuan mengenai pekerjaan dan keterampilannya. Untuk itu diperlukan adanya pelatihan guna menambah pengetahuan dan keterampilan para karyawan. Berdasarkan Tata Tertib Karyawan BMT-UGT Sidogiri Pasal 1 ayat 9 tentang kewajibankewajiban, bahwasannya setiap karyawan diwajibkan mengikuti kegiatan yang diadakan oleh Koperasi UGT berupa pelatihan yang bersangkutan dengan tugasnya.

4. Creativeness : yaitu keaslian gagasan-gagasan yang dimunculkan dan tindakantindakan untuk menyelesaikan persoalan-persoalan yang timbul. Berdasarkan Job Description Karyawan Koperasi BMT - UGT Sidogiri bagian account officer (AO) poin 9 menyatakan bahwa AO bertugas menyelesaikan dengan cepat dan tepat setiap komplain anggota.

5. Cooperative : kesediaan untuk bekerja sama dengan orang lain (sesama karyawan). Berdasarkan Tata Tertib Karyawan BMT-UGT Sidogiri Pasal 1 ayat 4 tentang kewajiban-kewajiban, 
bahwasannya setiap karyawan diwajibkan menjaga keharmonisan hubungan antar karyawan dan masyarakat.

6. Dependability : kesadaran dan dapat dipercaya dalam hal kehadiran. Berdasarkan Tata Tertib Karyawan BMT-UGT Sidogiri Pasal 1 ayat 1 tentang kewajibankewajiban, bahwasannya setiap karyawan diwajibkan hadir di tempat kerja tepat pada waktu yang ditentukan.

7. Personal qualities : yaitu menyangkut kepribadian, keramahtamahan, dan integritas pribadi. Berdasarkan Tata Tertib Karyawan BMT-UGT Sidogiri Pasal 1 ayat 3 tentang kewajibankewajiban, bahwasannya setiap karyawan diwajibkan melaksanakan tugas yang diberikan dengan semestinya dan memberikan pelayanan dengan baik serta mematuhi instruksi atasannya.

\section{Hubungan Pelatihan dengan Kinerja \\ Karyawan}

Pelatihan diberikan kepada sumber daya insani dalam BMT agar organisasi tersebut dapat terus berkembang dengan perubahanperubahan yang terjadi sehingga sumber daya insani dapat memberikan kontribusi lebih kepada BMT. Pelatihan yang berhasil adalah yang mampu memberikan sesuatu yang membawa kebaikan kepada para peserta pelatihan. Handoko (1998:136) menyatakan bahwa :

Kebutuhan akan pelatihan merupakan kegunaan penilaian kinerja karena dengan kinerja yang buruk mungkin menunjukkan kebutuhan pelatihan. Demikian juga, kinerja yang baik mungkin mencerminkan potensi yang harus dikembangkan. Dengan adanya program pelatihan yang diselenggarakan untuk meningkatkan kemampuan dan keterampilan kerja karyawan mempengaruhi kinerja karyawan tersebut. Menurut Sinn (dalam Meldona, 2009 : 261) mengatakan bahwa:

Islam mendorong pelatihan kepada karyawan dengan tujuan mengembangkan kompetensi dan kemampuan teknis karyawan dalam menunaikan tanggung jawab pekerjaannya.

Simamora (2002:346) mengatakan bahwa:

Salah satu tujuan pelatihan adalah memperbaiki kinerja, dimana karyawan yang bekerja secara tidak memuaskan karena kurangnya keterampilan. Kendatipun pelatihan tidak dapat memecahkan semua masalah kinerja yang tidak efektif, program pelatihan yang efektif kerap bermanfaat meminimalkan masalah ini. Hasibuan (2005:84) menyatakan bahwa :

Apabila kinerja karyawan setelah mengikuti pelatihan, baik kualitas maupun 
JESTT Vol. 1 No. 1 Januari 2014

kuantitas kinerjanya semakin baik, maka berarti metode pelatihan yang dilakukan cukup baik. Tetapi, jika kinerjanya tetap, berarti metode pelatihan yang dilakukan kurang baik, jadi perlu diadakan perbaikan. 


\section{E. Model Analisis}

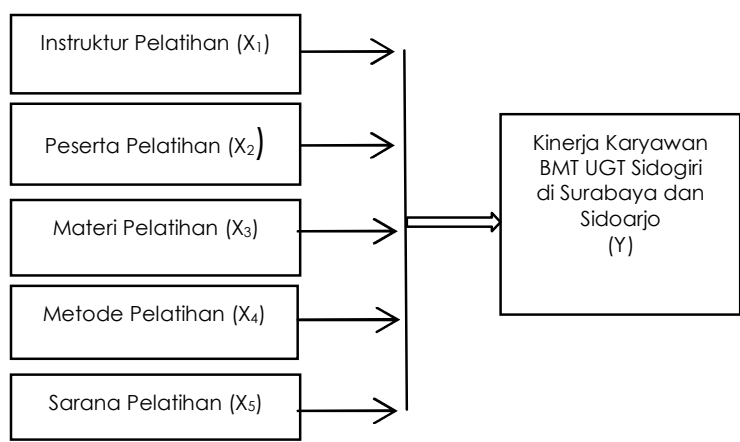

Sumber : Hasibuan

(2005:75-

76),"Manajemen Sumber Daya Manusia. Edisi Revisi", diolah.

Dengan perhitungan sebagai berikut :

$$
Y=a+b_{1} X_{1}+b_{2} X_{2}+b_{3} X_{3}+b_{4} X_{4}+b_{5} X_{5}
$$

ei

\section{Dimana :}

Y

$\begin{array}{ll} & \text { BMT UGT Sidogiri di } \\ & \text { Surabaya dan } \\ & \text { Sidoarjo }\end{array}$

$$
\begin{aligned}
& \mathrm{X}_{1}=\text { Instruktur Pelatihan } \\
& \mathrm{X}_{2} \quad=\text { Peserta Pelatihan } \\
& x_{3} \quad=\text { Materi Pelatihan } \\
& \mathrm{X}_{4} \quad=\text { Metode Pelatihan } \\
& X_{5} \quad=\text { Sarana Pelatihan } \\
& \mathrm{a}=\text { Konstanta } \\
& \mathrm{b}_{1}, \mathrm{~b}_{2}, \mathrm{~b}_{3}, \mathrm{~b}_{4}, \mathrm{~b}_{5}=\text { Koefisien Regresi } \\
& \text { ei } \quad=\text { Variabel error }
\end{aligned}
$$

\section{METODOLOGI PENELITIAN}

\section{A. Pendekatan Penelitian}

Penelitian ini menggunakan pendekatan kuantitatif yakni dengan mengadakan pengujian hipotesis, pengukuran data, dan pembuatan kesimpulan. Pendekatan kuantitatif adalah suatu proses penelitian untuk menemukan pengetahuan yang menggunakan data berupa angka sebagai alat menganalisis keterangan mengenai apa yang ingin diketahui (Kasiram,2008 : 149)

\section{B. Identifikasi Variabel}

Variabel penelitian menurut Sugiyono (2012 : 38) pada dasarnya adalah segala sesuatu yang berbentuk apa saja yang ditetapkan oleh peneliti untuk dipelajari sehingga diperoleh informasi tentang hal tersebut, kemudian ditarik kesimpulan. Penelitian ini menggunakan dua variabel, yaitu variabel eksogen dan variabel endogen.

1. Variabel Eksogen $(X)$

Variabel eksogen adalah variabel yang dapat mempengaruhi perubahan dalam variabel endogen dan mempunyai hubungan yang positif ataupun negatif bagi variabel endogen. Variabel eksogen dalam penelitian ini adalah pelatihan sumber daya insani $(X)$ yang terdiri dari instruktur pelatihan $\left(X_{1}\right)$, peserta pelatihan $\left(X_{2}\right)$, materi pelatihan $\left(X_{3}\right)$, metode pelatihan $\left(X_{4}\right)$, dan sarana pelatihan $\left(X_{5}\right)$.

2. Variabel Endogen $(Y)$

Variabel endogen merupakan variabel yang dipengaruhi oleh variabel lain yakni variabel yang diprediksi oleh satu atau beberapa variabel lain. Variabel endogen dalam penelitian ini adalah kinerja karyawan BMT UGT Sidogiri di Surabaya dan Sidoarjo (Y).

\section{Prosedur Pengumpulan Data}


Teknik pengambilan sampel yang digunakan dalam penelitian ini adalah Non Probality Sampling dimana menurut Sugiyono (2012 : 84) merupakan teknik pengambilan sampel yang tidak memberi peluang atau kesempatan sama bagi setiap unsur atau anggota populasi untuk dipilih menjadi sampel.

Sedangkan penentuan sampel menggunakan metode sampling jenuh yang merupakan teknik penentuan sampel bila semua anggota populasi digunakan sebagai sampel (Sugiyono, 2012 : 85). Teknik ini dilakukan bila jumlah populasi relatif kecil, kurang dari 100.

Adapun data yang digunakan dalam penelitian ini adalah data primer dihasilkan dari jawaban responden, yaitu karyawan BMT UGT Sidogiri atas penyebaran kuisioner dan data sekunder yang didapat dari dokumen BMT UGT Sidogiri, internet, dan literatur-literatur serta sumber-sumber lain yang berhubungan dengan permasalahan yang diteliti.

\section{Pengujian dan Teknik Analisis Data}

Instrumen yang baik harus memenuhi dua persyaratan penting yaitu valid dan reliabel (Arikunto,1989:136). Suatu data yang digunakan dalam sebuah penelitian dapat dikategorikan baik apabila telah memenuhi dua syarat kesahihan penelitian yakni uji validitas dan uji reliabilitas. Data yang telah terkumpulkan akan dianalisis dengan menggunakan teknik analisis regresi linier berganda (Linier Multiple Regression). Analisis ini dilakukan untuk mengetahui pengaruh atau hubungan variabel eksogen (instruktur pelatihan, peserta pelatihan, materi pelatihan, metode pelatihan dan sarana pelatihan) dan variabel endogen (kinerja karyawan BMT UGT Sidogiri di Surabaya dan Sidoarjo).

Uji statistik yang akan dilakukan untuk mengetahui apakah terdapat gejala penyimpangan dalam model regresi linier berganda yang digunakan dalam penelitian ini, yakni uji multikolinearitas dan uji heteroskedastisitas, (Gujarati, 2003: 63-75). Sedangkan untuk pengujian hipotesis dalam penelitian ini menggunakan uji $F$ dan uji t.

IV. HASIL PENELITIAN DAN PEMBAHASAN

A. Uji Validitas

Hasil Uji Validitas Variabel Pelatihan Sumber Daya Insani

\begin{tabular}{|c|c|c|c|}
\hline $\begin{array}{c}\text { Varia } \\
\text { bel }\end{array}$ & $\begin{array}{c}\text { Indika } \\
\text { tor }\end{array}$ & $\begin{array}{l}\text { Correct } \\
\text { ed item }\end{array}$ & Keterangan \\
\hline $\begin{array}{l}\text { Instruk } \\
\text { tur } \\
\text { Pelati } \\
\text { han }\end{array}$ & $\begin{array}{l}X 1.1 \\
X 1.2 \\
X 1.3 \\
X 1.4\end{array}$ & $\begin{array}{l}0,377 \\
0,611 \\
0,416 \\
0,591\end{array}$ & $\begin{array}{l}\text { Valid } \\
\text { Valid } \\
\text { Valid } \\
\text { Valid }\end{array}$ \\
\hline $\begin{array}{c}\text { Pesert } \\
\text { a } \\
\text { Pelati } \\
\text { han }\end{array}$ & $\begin{array}{l}X 2.1 \\
X 2.2 \\
X 2.3 \\
X 2.4 \\
\end{array}$ & $\begin{array}{l}0,735 \\
0,707 \\
0,457 \\
0,479\end{array}$ & $\begin{array}{l}\text { Valid } \\
\text { Valid } \\
\text { Valid } \\
\text { Valid }\end{array}$ \\
\hline $\begin{array}{c}\text { Materi } \\
\text { Pelati } \\
\text { han }\end{array}$ & $\begin{array}{l}\text { X3.1 } \\
\text { X3.2 } \\
\text { X3.3 } \\
\text { X3.4 } \\
\end{array}$ & $\begin{array}{l}0,603 \\
0,391 \\
0,640 \\
0,563\end{array}$ & $\begin{array}{l}\text { Valid } \\
\text { Valid } \\
\text { Valid } \\
\text { Valid }\end{array}$ \\
\hline $\begin{array}{c}\text { Meto } \\
\text { de } \\
\text { Pelati } \\
\text { han }\end{array}$ & $\begin{array}{l}X 4.1 \\
X 4.2 \\
X 4.3 \\
X 4.4 \\
\end{array}$ & $\begin{array}{l}0,605 \\
0,518 \\
0,563 \\
0,642\end{array}$ & $\begin{array}{l}\text { Valid } \\
\text { Valid } \\
\text { Valid } \\
\text { Valid }\end{array}$ \\
\hline $\begin{array}{c}\text { Saran } \\
\text { a } \\
\text { Pelati } \\
\text { han }\end{array}$ & $\begin{array}{l}X 5.1 \\
X 5.2 \\
X 5.3 \\
\times 5.4 \\
\end{array}$ & $\begin{array}{l}0,676 \\
0,777 \\
0,456 \\
0,413\end{array}$ & $\begin{array}{l}\text { Valid } \\
\text { Valid } \\
\text { Valid } \\
\text { Valid }\end{array}$ \\
\hline
\end{tabular}

seluruh indikator variabel pelatihan sumber daya insani mempunyai nilai 
validitas yang lebih besar dari $r$ standar yaitu 0,3 sehingga seluruh item dinyatakan valid.

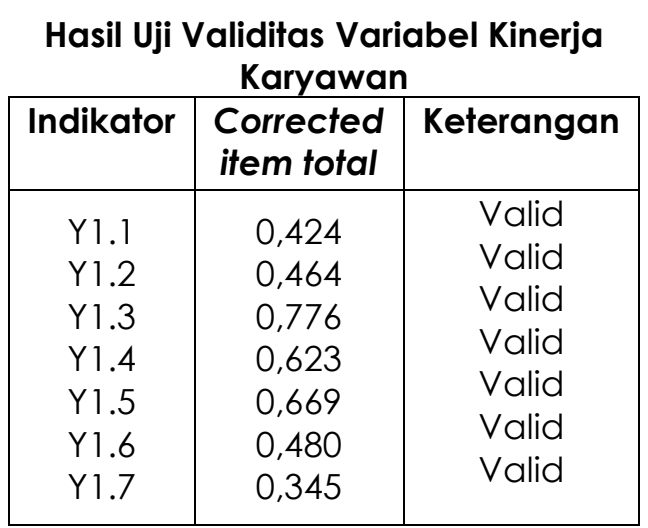

Tabel diatas menunjukkan bahwa seluruh indikator variabel kinerja karyawan mempunyai nilai validitas yang lebih besar dari $r$ standar yaitu 0,3 sehingga seluruh item dinyatakan valid. Dari hasil ini baik pada variabel eksogen dan variabel endogen valid sehingga dapat dilanjutkan pada pengujian selanjutnya.

\section{B. Uji Reliabilitas}

Koefisien Reliabilitas

\begin{tabular}{|c|c|c|}
\hline Variabel & Koef. Alpha & Keterangan \\
\hline $\begin{array}{c}\text { Instruktur } \\
\text { Pelatihan }\end{array}$ & 0,708 & Reliabel \\
\hline $\begin{array}{c}\text { Peserta } \\
\text { Pelatihan }\end{array}$ & 0,782 & Reliabel \\
\hline $\begin{array}{c}\text { Materi } \\
\text { Pelatihan }\end{array}$ & 0,750 & Reliabel \\
\hline $\begin{array}{c}\text { Metode } \\
\text { Pelatihan }\end{array}$ & 0,766 & Reliabel \\
\hline $\begin{array}{c}\text { Sarana } \\
\text { Pelatihan }\end{array}$ & 0,762 & Reliabel \\
\hline $\begin{array}{c}\text { Kinerja } \\
\text { Karyawan }\end{array}$ & 0,798 & Reliabel \\
\hline
\end{tabular}

Dalam tabel diatas menunjukkan bahwa masing-masing variabel baik dari variabel pelatihan sumber daya insani dan kinerja karyawan mempunyai koefisien alpha lebih besar dari 0,6. Dengan demikian item pengukuran pada masing-masing elemen dinyatakan reliabel dan selanjutnya dapat digunakan dalam penelitian.

\section{Analisis Regresi Linier Berganda}

Analisis Regresi Linier Berganda

\begin{tabular}{|c|c|c|c|}
\hline Variabel & $\begin{array}{l}\text { Koef. } \\
\text { Reg }\end{array}$ & t hitung & Signifikan \\
\hline Konstanta & 0,061 & 0,238 & 0,814 \\
\hline $\begin{array}{l}\text { Instruktur } \\
\text { Pelatihan }\end{array}$ & 0,206 & 3,770 & 0,001 \\
\hline $\begin{array}{c}\text { Peserta } \\
\text { Pelatihan }\end{array}$ & 0,262 & 3,549 & 0,001 \\
\hline $\begin{array}{c}\text { Materi } \\
\text { Pelatihan }\end{array}$ & 0,152 & 2,924 & 0,007 \\
\hline $\begin{array}{l}\text { Metode } \\
\text { Pelatihan }\end{array}$ & 0,123 & 2,196 & 0,037 \\
\hline $\begin{array}{c}\text { Sarana } \\
\text { Pelatihan }\end{array}$ & 0,237 & 5,420 & 0,000 \\
\hline \multicolumn{2}{|c|}{$\begin{array}{c}\text { Koefisien } \\
\text { determinasi }\left(\mathrm{R}^{2}\right)\end{array}$} & \multicolumn{2}{|c|}{0,921} \\
\hline \multicolumn{2}{|c|}{$\begin{array}{c}\text { Koefisien Korelasi } \\
\text { (R) }\end{array}$} & \multicolumn{2}{|c|}{0,960} \\
\hline \multicolumn{2}{|c|}{ F Hitung } & \multicolumn{2}{|c|}{65,390} \\
\hline \multicolumn{2}{|c|}{ Signifikansi } & \multicolumn{2}{|c|}{0,000} \\
\hline
\end{tabular}

\section{Koefisien Determinasi}

Kemampuan variabel eksogen dalam menerangkan atau menjelaskan perubahan variabel endogen dapat dilihat dari nilai koefisien determinasi berganda $\left(R^{2}\right)$. semakin tinggi nilai $R^{2}$ maka semakin baiklah model tersebut. Nilai dari $\mathrm{R}^{2}$ berkisar antara 0 sampai 1 , semakin mendekati 1 maka semakin baik kemampuan variabel eksogen dalam menjelaskan variabel endogen dalam model. Nilai dari koefisien determinasi dari hasil perhitungan adalah 0,921 yang 
berarti bahwa sebesar 92,1 \% kinerja karyawan (variabel endogen) dipengaruhi oleh variabel eksogen yang dimasukkan dalam model yaitu pelatihan sumber daya insani yang terdiri instruktur pelatihan, peserta pelatihan, materi pelatihan, metode pelatihan dan sarana pelatihan, sedangkan sisanya sebesar 7,9 $\%$ dipengaruhi oleh variabel lain yang tidak dimasukkan dalam model.

\section{E. Koefisien Korelasi Berganda}

Berdasarkan hasil analisis regresi berganda diperoleh nilai koefisien korelasi berganda atau Multiple (R) sebesar 0,960. Koefisien ini menunjukkan tingkat hubungan atau korelasi variabel endogen (Y) kinerja karyawan, terhadap variabelvariabel eksogen instruktur pelatihan, peserta pelatihan, materi pelatihan, metode pelatihan dan sarana pelatihan. Nilai $R$ yang sangat tinggi, yaitu sebesar 0,960 menunjukkan adanya hubungan yang sangat kuat antara semua variabel eksogen instruktur pelatihan, peserta pelatihan, materi pelatihan, metode pelatihan dan sarana pelatihan dengan variabel endogen kinerja karyawan $(Y)$.

\section{F. Koefisien Regresi}

Berdasarkan tabel diatas, maka persamaan regresi yang dapat dibuat adalah sebagai berikut :

$$
Y=0,061+0,206 X_{1}+0,262 X_{2}+
$$

$0,152 X_{3}+0,123 X_{4}+0,237 X_{5}$

$$
\text { Dimana: } \quad \begin{array}{ll}
Y=\text { Kinerja Karyawan } \\
\\
X_{1}=\text { Instruktur Pelatihan } \\
& X_{2}=\text { Peserta Pelatihan } \\
& X_{3}=\text { Materi Pelatihan } \\
& X_{4}=\text { Metode Pelatihan }
\end{array}
$$

$$
X_{5}=\text { Sarana Pelatihan }
$$

Koefisien regresi yang bertanda positif menunjukkan perubahan yang searah antara variabel eksogen terhadap variabel endogen.

\section{G. Pengujian Hipotesis}

\section{Hasil Uji Regresi Secara Simultan (Uji F)}

\begin{tabular}{|c|c|}
\hline F Hitung & 65,390 \\
\hline Signifikansi & 0,000 \\
\hline
\end{tabular}

Nilai $\mathrm{F}$ hasil regresi adalah sebesar

65,390, dengan nilai probabilitas kesalahan (Sig) sebesar 0,000. Nilai signifikansi ini lebih kecil dari 0,05 sehingga ada pengaruh secara bersama - sama variabel pelatihan sumber daya insani yang terdiri instruktur pelatihan, peserta pelatihan, materi pelatihan, metode pelatihan dan sarana pelatihan terhadap kinerja karyawan BMT UGT Sidogiri di Surabaya dan Sidoarjo. Dengan demikian hipotesis pertama diterima kebenarannya.

Hasil Uji Regresi Secara Parsial (Uji

t)

\begin{tabular}{|c|c|c|}
\hline Variabel & $\mathbf{t}$ & $\begin{array}{c}\text { Tingkat } \\
\text { signifikansi }\end{array}$ \\
\hline $\begin{array}{c}\text { Instruktur } \\
\text { Pelatihan }\end{array}$ & 3,770 & 0,001 \\
\hline $\begin{array}{c}\text { Peserta } \\
\text { Pelatihan }\end{array}$ & 3,549 & 0,001 \\
\hline $\begin{array}{c}\text { Materi } \\
\text { Pelatihan }\end{array}$ & 2,924 & 0,007 \\
\hline $\begin{array}{c}\text { Metode } \\
\text { Pelatihan }\end{array}$ & 2,196 & 0,037 \\
\hline $\begin{array}{c}\text { Sarana } \\
\text { Pelatihan }\end{array}$ & 5,420 & 0,000 \\
\hline \multicolumn{2}{|c|}{ Nilai signifikansi pada masing- } \\
\hline
\end{tabular}

masing variabel eksogen lebih kecil dari 0,05 sehingga ada pengaruh secara parsial variabel pelatihan sumber daya insani yang terdiri instruktur pelatihan, peserta pelatihan, materi pelatihan, 
metode pelatihan dan sarana pelatihan terhadap kinerja karyawan BMT UGT Sidogiri di Surabaya dan Sidoarjo. Dengan demikian hipotesis kedua diterima kebenarannya.

\begin{tabular}{|c|c|}
\multicolumn{2}{|c|}{ Perhitungan Nilai Beta } \\
\hline Variabel & Beta \\
\hline $\begin{array}{c}\text { Instruktur } \\
\text { Pelatihan }\end{array}$ & 0,236 \\
\hline $\begin{array}{c}\text { Peserta } \\
\text { Pelatihan }\end{array}$ & 0,306 \\
\hline $\begin{array}{c}\text { Materi } \\
\text { Pelatihan }\end{array}$ & 0,182 \\
\hline $\begin{array}{c}\text { Metode } \\
\text { Pelatihan }\end{array}$ & 0,177 \\
\hline $\begin{array}{c}\text { Sarana } \\
\text { Pelatihan }\end{array}$ & 0,374 \\
\hline
\end{tabular}

Hipotesis ketiga menyebutkan

bahwa "Materi pelatihan memiliki pengaruh yang dominan terhadap kinerja karyawan BMT UGT Sidogiri di Surabaya dan Sidoarjo.". Namun dari hasil pengujian menunjukkan nilai beta untuk variabel sarana pelatihan merupakan variabel yang berpengaruh dominan dengan nilai beta terbesar yaitu 0,374. Ini berarti dari lima variabel pelatihan sumber daya insani maka variabel sarana pelatihan yang berpengaruh dominan pada kinerja karyawan. Sehingga hipotesis ketiga tidak diterima kebenarannya.

\section{H. Uji Multikolinearitas}

Hasil Uji Multikolinearitas

\begin{tabular}{|c|c|c|}
\hline Variabel & $\begin{array}{c}\text { Nilai } \\
\text { VIF }\end{array}$ & Keterangan \\
\hline $\begin{array}{c}\text { Instruktur } \\
\text { Pelatihan }\end{array}$ & 1,388 & $\begin{array}{c}\text { Tidak terjadi } \\
\text { multikolinieritas }\end{array}$ \\
\hline $\begin{array}{c}\text { Peserta } \\
\text { Pelatihan }\end{array}$ & 2,640 & $\begin{array}{c}\text { Tidak terjadi } \\
\text { multikolinieritas }\end{array}$ \\
\hline $\begin{array}{c}\text { Materi } \\
\text { Pelatihan }\end{array}$ & 1,382 & $\begin{array}{c}\text { Tidak terjadi } \\
\text { multikolinieritas }\end{array}$ \\
\hline $\begin{array}{c}\text { Metode } \\
\text { Pelatihan }\end{array}$ & 2,312 & $\begin{array}{c}\text { Tidak terjadi } \\
\text { multikolinieritas }\end{array}$ \\
\hline Sarana & 1,694 & Tidak terjadi \\
\hline
\end{tabular}

\begin{tabular}{|c|c|}
\hline Pelatihan & multikolinieritas \\
\hline Berdasarkan tabel diatas diketahui
\end{tabular}

bahwa semua variabel eksogen mempunyai nilai $\mathrm{VIF}<5$. Hal ini dapat disimpulkan bahwa pada model regresi tidak terjadi Multikolinearitas.

\section{Uji Heteroskedastisitas}

Hasil Uji Heterokedastisitas

\begin{tabular}{|c|c|c|c|}
\hline $\begin{array}{c}\text { Variab } \\
\text { el }\end{array}$ & $\begin{array}{c}\text { Koef. } \\
\text { Rank } \\
\text { Spearm } \\
\text { an }\end{array}$ & $\begin{array}{c}\text { Signifika } \\
\text { nsi }\end{array}$ & $\begin{array}{c}\text { Keteranga } \\
\mathbf{n}\end{array}$ \\
\hline $\begin{array}{c}\text { Instrukt } \\
\text { ur } \\
\text { Pelatih } \\
\text { an }\end{array}$ & 0,149 & 0,402 & $\begin{array}{c}\text { Homosked } \\
\text { astis }\end{array}$ \\
\hline $\begin{array}{c}\text { Peserta } \\
\text { Pelatih } \\
\text { an }\end{array}$ & $-0,085$ & 0,634 & $\begin{array}{c}\text { Homosked } \\
\text { astis }\end{array}$ \\
\hline $\begin{array}{c}\text { Materi } \\
\text { Pelatih } \\
\text { an }\end{array}$ & 0,087 & 0,626 & $\begin{array}{c}\text { Homosked } \\
\text { astis }\end{array}$ \\
\hline $\begin{array}{c}\text { Metod } \\
\text { e } \\
\text { Pelatih } \\
\text { an }\end{array}$ & 0,120 & 0,499 & $\begin{array}{c}\text { Homosked } \\
\text { astis }\end{array}$ \\
\hline $\begin{array}{c}\text { Sarana } \\
\text { Pelatih } \\
\text { an }\end{array}$ & 0,115 & 0,518 & Homosked \\
astis \\
\hline \multicolumn{2}{|c|}{ Dari tabel diatas dapat dilihat } \\
\hline
\end{tabular}

bahwa nilai signifikasi untuk semua variabel lebih besar dari 0,05 dengan demikian dapat disimpulkan bahwa terjadi gejala homoskedastis atau tidak terjadi hubungan antara variabel pengganggu dengan variabel eksogen, sehingga variabel endogen benar-benar hanya dijelaskan oleh variabel eksogen.

\section{SIMPULAN}

Berdasarkan analisis dan pembahasan yang telah dilakukan, maka kesimpulan yang dapat diambil adalah :

1. Ada pengaruh secara simultan yang signifikan pelatihan sumber daya insani 
yang terdiri dari instruktur pelatihan, peserta pelatihan, materi pelatihan, metode pelatihan dan sarana pelatihan terhadap kinerja karyawan BMT UGT Sidogiri di Surabaya dan Sidoarjo berdasarkan dari hasil uji $\mathrm{F}$ hasil regresi adalah sebesar 65,390, dengan nilai probabilitas kesalahan (Sig) sebesar 0,000 yang nilai signifikansinya kurang dari 0,05 . Hasil ini menunjukkan bahwa pelatihan sumber daya insani terbukti dapat mempengaruhi kinerja karyawan. Besarnya kontribusi pelatihan sumber daya insani terbukti terhadap kinerja karyawan adalah $92,1 \%$ dengan $7,9 \%$ lainnya ditentukan oleh variabel lain. Arah koefisien regresi dari seluruh variabel adalah positif yang berarti semakin meningkat instruktur pelatihan, peserta pelatihan, materi pelatihan, metode pelatihan dan sarana pelatihan maka semakin meningkat pula kinerja karyawan.

2. Pada pengujian secara parsial juga diketahui bahwa seluruh variabel eksogen tersebut berpengaruh secara signifikan terhadap kinerja karyawan. Nilai signifikansi pada masing-masing variabel eksogen lebih kecil dari 0,05 sehingga ada pengaruh secara parsial variabel pelatihan sumber daya insani yang terdiri instruktur pelatihan, peserta pelatihan, materi pelatihan, metode pelatihan dan sarana pelatihan terhadap kinerja karyawan BMT UGT Sidogiri di Surabaya dan Sidoarjo.
3. Variabel sarana pelatihan merupakan variabel yang berpengaruh dominan terhadap kinerja karyawan dengan nilai beta terbesar yaitu 0,374. Pengaruh dominan tersebut menunjukkan bahwa sarana pelatihan merupakan aspek yang paling diperhatikan untuk memperbaiki kinerja karyawan BMT UGT Sidogiri di Surabaya dan Sidoarjo.

\section{DAFTAR PUSTAKA}

Anonim, 2010. Al-Quranku. Dengan Tajwid Blok Warna. Arab-Latin-Terjemah. Jakarta : DEPAG RI.

Arikunto, Suharsimi. 1989. Prosedur Penelitian :Suatu Pendekatan Praktek. Edisi Revisi V. Jakarta ; Bina Aksara.

Gomes, Faustino Cardoso. 2000. Manajemen Sumber Daya Manusia. Edisi Pertama. Yogyakarta : Andi offset.

Gujarati, Damodar. 2003. Ekonometrika

Dasar : Edisi Keenam. Jakarta:

Erlangga.

Handoko, T. Tani. 1998. Manajemen Personalia dan Sumber Daya Manusia. Edisi Kedua. Yogyakarta : Badan Penerbitan Fakultas Ekonomi Universitas Gajah Mada.

Hardjana, M. Agus. 2001. Training Sumber Daya Manusia Yang Efektif. Edisi Kedua. Yogyakarta : Kanisius.

Hasibuan, M.S.P. 2005. Manajemen Sumber Daya Manusia. Edisi Revisi. Jakarta: Bumi Aksara.

Kasiram, H. Moh. 2008. Metodologi Penelitian Kualitatif-Kuantitatif. Malang: UIN Malang Press 
Mangkunegara, A.A.Anwar Prabu. 2000. Manajemen Sumber Daya Perusahaan. Bandung : PT. Remaja Rosdakarya.

Meldona. 2009. Manajemen Sumber Daya Manusia. Malang : UIN Malang Press.

Moekijat. 1991. Latihan dan Pengembangan Layanan Pegawai. Bandung : Mandar Maju.

Panggabean, Mutiara S. 2002. Manajemen Sumber Daya Manusia.Cetakan Pertama. Jakarta : Ghalia Indonesia.

Permitasari, Ami Vintya. 2012. Pengaruh Dimensi Pelatihan terhadap Kinerja Karyawan pada badan Pusat statistik Kabupaten Magetan. Skripsi tidak diterbitkan. Malang : Universitas Brawijaya.

Rivai, Veithzal dan Ella Jauvani Sagala. 2010. Manajemen Sumber Daya Manusia untuk Perusahaan Dari Teori ke Praktik. Edisi kedua. Jakarta : PT Raja Grafindo Persada.

Republik Indonesia. Peraturan Pemerintah Nomor 31 Tahun 2006 tentang Sistem Pelatihan Kerja Nasional. 2006 :
Jakarta. Diperbanyak oleh Sekretariat Negara Rl.

Republik Indonesia. Undang - Undang Nomor 17 Tahun 2012 tentang Perkoperasian. 2012. Jakarta. Diperbanyak oleh Sekretariat Negara RI.

Ridwan, Ahmad Hasan. 2004. BMT \& Bank Islam Instrumen Lembaga Kevangan Syariah. Bandung: Pustaka Bani Quraisy.

Simamora, Henry. 2004. Manajemen Sumber Daya Manusia. Edisi Ketiga. Yogyakarta: STIE YKPN.

Sugiyono. 2012. Metodologi Penelitian Kuantitatif Kualitatif dan $R$ \& $D$. Bandung : Alfabeta.

Sutrisno, Edy. 2010. Manajemen Sumber Daya Manusia. Jakarta : Kencana Prenada Media Group. 


\title{
IMPLEMENTASI ISLAMIC CORPORATE SOCIAL RESPONSIBILITY (CSR) PADA PT. BUMI LINGGA PERTIWI DI KABUPATEN GRESIK
}

\author{
Indra Kharisma \\ Mahasiswa Program Studi S-1 Ekonomi Islam - Fakultas Ekonomi dan Bisnis - Universitas \\ Airlangga \\ Email: indrakha1709@gmail.com \\ Imron Mawardi \\ Departemen Ekonomi Syariah - Fakultas Ekonomi dan Bisnis - Universitas Airlangga \\ Email: ronmawardi@gmail.com
}

\begin{abstract}
Implementation of Corporate Social Responsibility (CSR) is used later to improve the image of the company and its business existence. Instead of CSR to empower people its delude people with a profit motive. Islamic CSR is that CSR refers to business practices that have an ethical responsibility Islamically, companies incorporate Islamic norms characterized by sincerity commitment in maintaining the social contract in its business practices in halal lawful. This study aimed to reveal the implementation of Islamic CSR PT. Bumi Lingga Pertiwi Gresik.

This study used a qualitative approach with descriptive case study method. The selections of informant are using purposive sampling method. Data collection was conducted by semi-structured interviews and documentation. Analysis of the data using descriptive method.

The results of this study indicate that PT. Bumi Lingga Pertiwi has implemented Islamic CSR based on unity, caliphate, justice and broterhood by creating and running a cooperation agreement in accordance with sharia corridor, provide good service to customers, act fairly and avoid discrimination, provide assistance to the poor in the villages around, helping the development of education and worship, as well as participate protecting the environment by way of planting trees together.
\end{abstract}

\section{Keywords: CSR, Islamic CSR}

\section{PENDAHULUAN}

\section{A. Latar Belakang}

Selama dua puluh tahun terakhir, CSR telah berkembang sebagai kerangka kerja untuk peran bisnis dalam masyarakat (Dusuki \& Abdullah, 2005). Dalam perkembangannya, khususnya di negaranegara berkembang, CSR sangat diharapkan serta dipercaya berperan mengatasi masalah di masyarakat dimana bisnis tersebut beroperasi. Istilah Corporate Social Responsibility (CSR), pertama kali muncul dalam tulisan Sosial Responsibility of the Businessman tahun 1953 sebagai konsep yang digagas Howard Rothmann Bowen ini dianggap 
dapat menjawab keresahan dunia bisnis. CSR diadopsi karena dianggap dapat menjadi penawar kesan buruk perusahaan yang terlanjur terbangun dalam pikiran masyarakat. Jika dilihat, latar belakang adopsi CSR oleh perusahaan sebagaimana diatas justru memberi kesan bahwa praktek CSR seolah hanya menjadi alat untuk membangun citra positif ditengah rusaknya perilaku korporat yang terjadi.

CSR di Barat didasarkan pada pandangan budaya Barat yang cenderung mengesampingkan nilai-nilai ketuhanan dan sangat berbeda dengan CSR Islam (Yusuf dan Bahari, 2011). Selain itu kecenderungan CSR di Barat lebih berorientasi ke dunia, dengan tujuan agar perusahaan dapat diterima oleh masyarakat dan mencari keuntungan bisnis semata. CSR adalah kegiatan yang tidak lepas dari etika bisnis. Etika bisnis merupakan dasar atau jiwa dari pelaksanaan sebuah unit usaha, sementara CSR merupakan manifestasinya. Oleh karena itu, sudah semestinya implementasi CSR diiringi dan dipandu oleh etika bisnis yang baik. Islam memiliki pedoman yang lengkap bagi umatnya dalam menjalani hidup, termasuk pedoman bagaimana sebuah bisnis dijalankan tanpa menjauhkannya dari etika, karena dalam Islam etika dan bisnis merupakan satu kesatuan yang tidak dapat dipisahkan.

Tanggung jawab sosial perusahaan bukanlah hal yang baru dalam Islam. Tanggung jawab sosial sudah mulai eksis dan diterapkan selama 14 abad terakhir. Pembahasan tanggung jawab sosial sering disebutkan dalam Al-Qur'an. Al Qur'an selalu menghubungkan kesuksesan bisnis dan pertumbuhan ekonomi yang sangat dipengaruhi oleh etika pengusaha dalam bisnis mereka. Meskipun ayat-ayat Al-Quran dan Hadits tidak langsung merujuk pada CSR tetapi ada banyak ayat dalam Al Qur'an dan Hadits yang menjelaskan kewajiban individu untuk menanggung kebutuhan orang lain. Oleh karena itu, individu yang bersama-sama untuk menciptakan sebuah perusahaan memiliki kewajiban untuk membantu masyarakat dan memberikan manfaat kepada orang lain.

Islamic CSR adalah CSR yang merujuk kepada praktik bisnis yang memiliki tanggung jawab etis secara Islami, perusahaan memasukkan normanorma agama Islam yang ditandai oleh adanya komitmen ketulusan dalam menjaga kontrak sosial di dalam praktik bisnisnya (Suharto, 2010: 101). Dengan demikian, praktik bisnis dalam kerangka Islamic CSR mencakup serangkaian kegiatan bisnis dalam berbagai bentuknya. Meskipun tidak dibatasi jumlah kepemilikan barang, jasa serta profitnya, namun cara-cara memperolehnya dan pendayagunaan hartanya dibatasi oleh aturan halal dan haram sesuai dengan syariah (Rivai, 2009).

PT. Bumi Lingga Pertiwi (PT. BLP) adalah sebuah perusahaan yang bergerak di bidang developer atau pengembang perumahan. PT. BLP 
sebagai sebuah perusahaan yang terdiri dari individu yang terbentuk dalam sebuah satu kesatuan memiliki tanggung jawab kepada setiap elemen di lingkungan bisnisnya, baik kepada internal maupun eksternal perusahaan. Tanggung jawab disini bermakna tanggung jawab kepada dzat yang tertinggi yaitu Allah Swt. sebagai Sang Pencipta, tanggung jawab diri sendiri dengan manusia lainnya, dengan alam dan semua makhluk lainnya, sementara secara operasionalnya, tanggung jawab menjalankan bisnis sesuai dengan aturan syariah, tanggung jawab untuk saling menghormati, saling hidup berdampingan, pelayanan yang baik, pengembangan organisasi dan karyawan serta perlindungan alam. Hal tersebut terwujud dengan menjaga akad-akad kerjasama, menghindari pendapatan yang tidak halal, mensejahterakan karyawannya dengan tunjangantunjangan, menciptakan suasana kerja yang aman dan nyaman, menjunjung tinggi persaudaraan dalam bekerja dan melestarikan serta melindungi lingkungan dengan cara melakukan tanam pohon serta memastikan aktivitas bisnisnya tidak merusak lingkungan. Selain itu PT. BLP juga tidak lupa membantu dan mendukung kesejahteraan sosial dengan membantu pembangunan sarana pendidikan dan sarana ibadah tanpa ada motif mencari keuntungan serta bersedekah kepada warga dusun miskin.

\section{LANDASAN \\ TEORI \\ PENGEMBANGAN PROPOSISI}

DAN

\section{A. Etika Bisnis}

Istilah etika diartikan sebagai suatu perbuatan standar (standard of conduct) yang memimpin individu dalam membuat keputusan. Etika bersumber dari moralitas yang merupakan sistem nilai tentang bagaimana kita harus hidup secara baik sebagai manusia (Keraf dan Sonny, 1991: 20). Baron (2006: 694) mendefinisikan etika sebagai suatu pendekatan sistematis atas pertimbangan moral berdasarkan penalaran, analisis, sintesis dan perenungan. Secara lebih khusus, makna etika bisnis menunjukkan perilaku etis maupun tidak etis yang dilakukan manajer dan karyawan dari suatu organisasi perusahaan (Griffin dan Ebert, 1999: 82). Etika bisnis disebut juga etika manajemen, yaitu penerapan standar moral ke dalam kegiatan bisnis (Alma \& Juni, 2009: 202).

\section{B. Sejarah Perkembangan Konsep Corporate Social Responsibility}

Konsep awal corporate social responsibility (CSR) secara eksplisit baru dikemukakan oleh Howard R. Bowen (Carroll, 1999) melalui karyanya yang berjudul "Social Responsibilities of the Businessmen". Steiner and John (1994: 105110) memandang rumusan Bowen mengenai tanggung jawab sosial yang dilakukan oleh pelaku bisnis sebagai kelanjutan dari pelaksanaan berbagai kegiatan derma (charity) sebagai wujud kecintaan manusia terhadap sesama manusia (philanthropy) yang banyak dilakukan oleh para pengusaha ternama 
pada akhir abad ke-19 sampai periode tahun 1930-an. Sejak kurun waktu tahun 1930-an sampai 1960-an, terdapat tiga tema cara pandang yang berkaitan untuk menjelaskan CSR yang digunakan oleh para pemimpin bisnis, yaitu trusteeship, balancing of interest and service yang telah memperoleh penerimaan yang semakin besar dari pelaku bisnis.

Periode awal tahun 1970-an mencatat babak penting perkembangan konsep CSR ketika para pimpinan perusahaan terkemuka di Amerika serta para peneliti yang diakui dalam bidangnya membentuk Committee for Economic Development (CED). Salah satu pernyataan CED (1971) yang dituangkan dalam laporan berjudul "Social Responsibilies of Business Corporation" menyebutkan:

"Saat ini, sudah jelas bahwa istilah kontrak sosial antara masyarakat dan pelaku usaha telah mengalami perubahan yang substansial dan penting. Pelaku bisnis dituntut untuk memikul tanggung jawab yang lebih luas kepada masyarakat dibanding waktu-waktu sebelumnya serta mengindahkan beragam nilai-nilai manusia. Perusahaan diminta untuk memberikan kontribusi lebih besar bagi kehidupan bangsa Amerika dan bukan sekedar memasok sejumlah barang dan jasa."

Selanjutnya CED membagi CSR ke dalam tiga lingkaran tanggung jawab, yakni inner circle of responsibilities, intermediate of responsibilities, dan outer circle of responsibilities. Lingkaran tanggung jawab terdalam (inner circle of responsibilities), lingkaran tanggung jawab pertengahan (intermediate of responsibilities), lingkaran tanggung jawab terluar (outer circle of responsibilities).

Di penghujung tahun 1980-an, The World Commission on Enviroment and Development yang lebih dikenal dengan The Brundtland Commission mengeluarkan laporan yang dipublikasikan oleh Oxford University Press berjudul "Our Common Future". Salah satu poin penting dalam laporan tersebut adalah diperkenalkannya konsep pembangunan berkelanjutan (sustainability development), yang didefinisikan oleh The Brundtland Commission sebagai berikut: "Pembangunan berkelanjutan adalah pembangunan yang dapat memenuhi kebutuhan manusia saat ini tanpa mengorbankan kemampuan generasi yang akan datang dalam memenuhi kebutuhan mereka". Pengenalan konsep sustainability development memberi dampak besar kepada perkembangan konsep CSR selanjutnya.

Sebagai adopsi atas konsep sustainable debelopment, saat ini perusahaan secara sukarela menyusun laporan setiap tahun yang dikenal dengan sustainability report atau beberapa perusahaan menggunakan nama corporate citizenship report. Laporan tersebut menguraikan dampak organisasi perusahaan terhadap tiga aspek, yakni dampak operasi perusahaan 
terhadap ekonomi, sosial, dan lingkungan. Salah satu model awal yang digunakan oleh perusahaan dalam menyusun sustainability report mereka adalah dengan mengadopsi metode akuntansi baru yang dinamakan triple bottom line. Menurut Elkington (1997), konsep triple bottom line merupakan perluasan dari konsep akuntansi tradisional yang hanya memuat bottom line tunggal yakni hasilhasil kevangan dari aktivitas ekonomi perusahaan. Secara lebih rinci, Elkington menjelaskan konsep tersebut sebagai berikut: Tiga garis dari triple bottom line mewakili masyarakat, ekonomi dan lingkungan.

\section{Ruang lingkup CSR}

CSR bekaitan dengan cara suatu bisnis bertindak terhadap kelompok dan pribadi lainnya dalam lingkungan sosialnya. Kelompok-kelompok dan individu tersebut disebut sebagai pihak pemercaya dalam organisasi (organizational stakeholders). Pihak pemercaya dalam organisasi yaitu kelompok, orang dan organisasi yang langsung dipengaruhi praktik-praktik suatu organisasi sehingga berkepentingan terhadap organisasi itu. Griffin \& Ebert (2003: 119) dalam Alma \& Juni (2009: 182) menyebutkan tujuh ruang lingkup dalam CSR dimana sebuah perusahaan harus bertanggung jawab kepada pihak-pihak tersebut yaitu, pelanggan, karyawan, investor, pemasok, dan komunitas lokal.

\section{Manfaat CSR}

Menurut Suharto (2010: 52-53) jika dikelompokkan, sedikitnya ada empat manfaat CSR terhadap perusahaan yaitu, pertama, Brand Differentiation dengan cara memberikan citra perusahaan yang khas, baik dan etis. Kedua, Human Resources dapat membantu dalam perekrutan karyawan baru, terutama yang memiliki kualifikasi tinggi, bagi staf lama, CSR juga dapat meningkatkan persepsi, reputasi dan motivasi dalam bekerja. Ketiga, License to Operate dapat mendorong pemerintah dan publik memberi "izin" atau "restu" bisnis. Keempat Risk Management berguna untuk mencegah dan mengurangi skandal korupsi, kecelakaan karyawan, atau kerusakan lingkungan.

\section{E. Implementasi CSR}

Keterlibatan perusahaan dalam tanggung jawab sosial dan moral dapat diimplementasikan dalam kegiatan bisnis perusahaan. Hal tersebut dimaksudkan agar tanggung jawab sosial dan moral itu benar-benar terlaksana. Agar implementasi tersebut dapat dilaksanakan, maka perusahaan harus mengetahu kondisi internal tertentu yang memungkinkan terwujudnya tanggung jawab sosial dan moral tersebut.

\section{Pendekatan CSR}

Menurut Wibisono (2007) terdapat empat model pola tanggung jawab sosial perusahaan yang umum diterapkan di Indonesia yaitu, pendekatan langsung, melalui yayasan atau organisasi sosial perusahaan, bermitra dengan pihak lain, mendukung atau bergabung dalam suatu konsorsium. 
Jika ditinjau dari motivasinya, tanggung jawab sosial perusahaan dapat dibedakan menjadi 4 dimensi, yaitu: corporate giving, corporate philanthropy, corporate community relations, dan community development. CSR sering diartikan sebagai kegiatan donasi perusahaan atau sekedar ketaatan perusahaan pada hukum dan aturan yang berlaku (misalnya taat pada aturan mengenai standar upah minimum, tidak memperkerjakan tenaga kerja di bawah umur, dan lain-lain). Padahal, kegiatan donasi (philanthropy) dan ketaatan perusahaan pada hukum tidak dapat dikatakan sebagai CSR. Kegiatan donasi dan ketaatan perusahaan pada hukum hanya syarat minimum agar perusahaan dapat beroperasi dan diterima oleh masyarakat (Wibisono, 2007).

Dapat dilihat bahwa tujuan kegiatan philanthrophy adalah kegiatan yang bersifat amal (charity). Sebuah kegiatan amal tidak memerlukan komitmen berkelanjutan dari perusahaan. Tanggung jawab perusahaan terhadap sebuah kegiatan philanthropy berakhir bersamaan dengan berakhirnya kegiatan amal yang dilakukan perusahaan tersebut. Lebih dari sekedar philanthropy atau sumbangan perusahaan, CSR adalah suatu komitmen bersama dari seluruh stakeholders perusahaan untuk bersama-sama bertanggung jawab terhadap masalah-masalah sosial. Jadi, CSR bukan merupakan sumbangan dari salah satu atau lebih stakeholder perusahaan (misalnya berusaha penyisihan keuntungan dari pemegang saham untuk kegiatan sosial), tetapi menjadi tanggungan seluruh stakeholders.

\section{Tahapan Perumusan Kegiatan} Tanggung Jawab Sosial Perusahaan

Dalam merumuskan keputusan yang tepat untuk melaksanakan tanggung jawab sosial perusahaan, para manajer dan perencana program melalui beberapa tahapan (Kotler, 2005: 18 - 21):

1. Memilih suatu masalah sosial Tahapan ini merupakan suatu tahap awal yang penting dilakukan untuk memutuskan satu dari beberapa masalah sosial yang ingin didukung. Keputusan awal ini mempunyai pengaruh yang besar pada program dan hasil berikutnya.

2. Memilih inisiatif untuk membuat kegiatan terhadap masalah sosial Ketika masalah sosial telah ditentukan, manajer akan ditantang untuk menentukan inisiatif apa yang akan dilakukan untuk memberikan perhatian pada masalah sosial tersebut.

3. Mengembangkan dan melaksanakan rencana program Pada poin ini keputusan yang diambil meliputi beberapa hal penting mengenai apakah pelaksanaan kegiatan harus bermitra dengan pihak lain atau tidak, dan siapakah mitra yang akan dipilih.

4. Evaluasi hasil 
Pengukuran yang dilakukan secara berkelanjutan di dalam kegiatan marketing dan investasi financial bagi perusahaan memiliki catatan panjang, dengan pengalaman yang cukup lama didalam membangun sistem acuan yang canggih dan data base yang menyediakan anlisis pengembalian investasi dan membandingkan aktifitas sekarang dengan target dan standar.

\section{F. Pandangan Islam terhadap CSR}

Konsep CSR yang dikembangkan di Barat tidak sama dengan konsep CSR dalam Islam. Yusuf dan Bahari (2011), menyebutkan dua perbedaannya, pertama perkembangan nilai-nilai dan budaya. Kedua adalah dasar atau prinsipprinsip nilai dan budaya. CSR dalam Islam dibangun atas dasar tasawur (pandangan dunia) dan epistemologi Islam yang berbeda dari CSR yang dikembangkan di Barat, Yusuf dan Bahari (2011).

Pada intinya, pengertian tanggung jawab sosial perusahaan secara Islam adalah sama dengan tanggung jawab sosial dari setiap individu muslim, yaitu menjalankan yang benar dan melarang atau menentang yang salah (Farook, 2007: 35). Pengertian benar (al-haq) dan salah (al-bathil) dapat diartikan sebagai dua hal yang tumpang tindih. Secara hukumnya, benar (haq) mengacu pada semua yang diperbolehkan atau dianjurkan (halal), sedangkan salah (bathil) mengacu pada semua yang tidak diperbolehkan atau tidak dianjurkan (haram). Dari perspektif hukum Islam, "benar" mengacu pada apa yang seharusnya sedangkan "salah" mengacu pada apa yang tidak adil (Farook, 2007: 35).

Tanggung jawab sosial perusahaan bukanlah hal yang baru dalam Islam. Tanggung jawab sosial sudah mulai eksis dan diterapkan selama 14 abad terakhir. Pembahasan tanggung jawab sosial sering disebutkan dalam Al-Qur'an. Al Qur'an selalu menghubungkan kesuksesan bisnis dan pertumbuhan ekonomi yang sangat dipengaruhi oleh etika pengusaha dalam bisnis mereka.

Islam memberikan perhatian terhadap bisnis melalui aspek moral untuk mencapai keuntungan maksimal. Hal ini menunjukkan bahwa Islam berkaitan dengan perekonomian dan moralitas, yang keduanya tidak dapat dipisahkan. Aspek ini juga ditegaskan oleh Nabi Muhammad Saw. Beliau mengatakan dalam hadist yang diriwayatkan oleh Malik bin Anas: " Seorang pekerja/karyawan berhak untuk setidaknya mendapatkan makanan yang baik dan pakaian dengan ukuran yang layak dan tidak dibebani dengan kemampuan untuk bekerja di luar batas". (Malik, 795, 2: 980).

Islam juga mempertimbangkan kelestarian lingkungan sebagai salah satu tanggung jawab sosial. Semua upaya bisnis harus memastikan kelestarian lingkungan (QS Al-Baqarah [2] ayat 204). Di dalam ayat tersebut dijelaskan 
bagaimana Islam memandang kelestarian lingkungan. Semua upaya bisnis atau non bisnis harus memastikan kelestarian lingkungan. Hubungan antara manusia dan lingkungan sangat dekat dan tidak bisa dipisahkan. Islam telah jelas melarang sesuatu yang berbahaya bagi individu atau lingkungan berbahaya.

Sementara di bidang kesejahteraan sosial, Islam mendorong untuk beramal kepada mereka yang membutuhkan dan keterbatasan kemampuan dalam bekerja melalui sadaqah dan pinjaman kesejahteraan (Qard hasan) (QS AtTaghaabun [64] ayat 16). Ayat ini menjelaskan tanggung jawab muslim untuk membantu orang lain melalui kontribusi amal dan sumbangan, dan kekikiran adalah kekejian di dalam Islam (Yusuf dan Bahari, 2011).

Menurut Yusuf dan Bahari (2011), selain mempengaruhi kesejahteraan sosial, tindakan pinjaman kebajikan juga dapat membawa manfaat ganda bagi individu dan perusahaan. Pertama, pinjaman kebajikan dapat menciptakan citra positif bagi individu dan perusahaan serta dan yang kedua, mendapatkan formasi jaringan bisnis baru yang dapat mengakibatkan peningkatan keuntungan.

Nabi Muhammad Saw. bersabda dalam sebuah hadits yang diriwayatkan oleh Salman bin Amir, "Sedekah bagi kaum miskin adalah amal. Dan amal untuk keluarga memiliki dua keuntungan, yaitu bermanfaat bagi Allah dan memperkuat persaudaraan." (HR. Tirmizi, 1993: Hadis Nomor 653).
Pernyataan diatas menunjukkan bahwa konsep tanggung jawab sosial dan konsep keadilan telah lama ada dalam Islam, selama seperti kehadiran Islam yang dibawa oleh Nabi Muhammad Saw. Nabi Muhammad Saw mewujudkan tanggung jawab sosial dan menciptakan keadilan sesuai dengan tuntunan $\mathrm{Al}$ Qur'an. Demikian juga praktek Nabi Muhammad Saw dalam penerapan tanggung jawab sosial dan keadilan dalam masyarakat menjadi sumber acuan bagi bimbingan kepada generasi berikutnya, yang dikenal sebagai As Sunnah. Kedua Al Qur'an dan As Sunnah telah sangat harmonis dalam menegakkan keadilan yang sejati.

Keberadaan umat muslim di muka bumi memiliki dua tugas, hamba yang taat kepada Allah dan khalifah yang adil (Yusuf dan Bahari, 2011). Hubungan antara kedua tugas utama tesebut haruslah sejalan dan tidak boleh dipisahkan satu sama lain. Sebagai seorang hamba yang menyembah Allah, setiap individu memiliki kewajiban untuk menjadikan semua peristiwa hidupnya sebagai bentuk pengabdian yang sempurna kepada Allah. Dalam hal ini, konsep ibadah perlu dipahami dalam arti yang lebih luas. Ini berarti bahwa selain dari ibadah khusus, setiap individu dituntut untuk melakukan ibadah umum lainnya, semua kegiatan yang membawa kesejahteraan manusia dan alam sesuai dengan kondisi tertentu, dengan niat yang benar dan harus memastikan 
bahwa tindakan-tindakan yang dilakukan sesuai syariah (Yusuf dan Bahari, 2011).

Oleh karena itu, kewajiban CSR Islam adalah tanggung jawab individu yang datang bersama-sama dalam satu perusahaan untuk memberikan dampak positif bagi lingkungan dalam rangka memberdayakan masyarakat yang lemah dan untuk melestarikan lingkungan alam (Yusuf dan Bahari, 2011).

\section{G. Perbedaan CSR dengan Islamic CSR}

Islamic CSR sangatlah berbeda dengan CSR dalam kelembagaan ekonomi sekuler yang di anut oleh perusahaan di Barat. CSR muncul sebagai respon atau jawaban dari terjadinya kesenjangan yang semakin lebar dari waktu ke waktu antara harapan tanggung jawab sosial terhadap lingkungan masyarakat dari bisnis atau corporate dengan kenyataan tanggung jawab sosial perusahaan. Kesenjangan tersebut menimbulkan masalah sosial yang sangan merugikan perusahaan dalam jangka pendek maupun jangka panjang. Perbedaan CSR dengan Islamic CSR akan dijelaskan secara singkat pada tabel 1 berikut ini:

Tabel 1: Perbedaan CSR dengan Islamic CSR

\begin{tabular}{|c|c|c|}
\hline $\begin{array}{c}\text { Keterang } \\
\text { an }\end{array}$ & Islamic CSR & CSR \\
\hline Motif & $\begin{array}{l}\text { Bentuk } \\
\text { pertanggung } \\
\text { jawaban } \\
\text { setiap } \\
\text { individu } \\
\text { kepada Allah } \\
\text { SWT Untuk } \\
\text { mencapai }\end{array}$ & $\begin{array}{l}\text { Menghindari } \\
\text { kerugian } \\
\text { bisnis }\end{array}$ \\
\hline
\end{tabular}

\begin{tabular}{|c|c|c|}
\hline & $\begin{array}{l}\text { misi dan } \\
\text { tujuan utama } \\
\text { dari bisnis } \\
\text { demi } \\
\text { terciptanya } \\
\text { kemaslahata } \\
\text { n bersama } \\
\text { dan } \\
\text { mencapai } \\
\text { falah }\end{array}$ & \\
\hline $\begin{array}{l}\text { Pelaksana } \\
\text { an }\end{array}$ & $\begin{array}{l}\text { Dilaksanakan } \\
\text { dengan ikhlas } \\
\text { meskipun } \\
\text { tidak terjadi } \\
\text { permasalaha } \\
n \text { sosial di } \\
\text { masyarakat } \\
\text { dan } \\
\text { dilaksanakan } \\
\text { sebagai } \\
\text { bentuk } \\
\text { penghamba } \\
\text { an kepada } \\
\text { Allah sWT } \\
\text { agar dapat } \\
\text { mencapai } \\
\text { idrak shilah } \\
\text { billah } \\
\text { (kedekatan } \\
\text { hubungan } \\
\text { dengan Allah } \\
\text { SWT karena } \\
\text { mendapat } \\
\text { ridho-Nya) } \\
\text { yang } \\
\text { mengacu } \\
\text { kepada } \\
\text { aturan halal- } \\
\text { haram. }\end{array}$ & $\begin{array}{l}\text { Dilaksanaka } \\
\mathrm{n} \quad \text { ketika } \\
\text { terjadi } \\
\text { permasalah } \\
\text { an sosial di } \\
\text { masyarakat, } \\
\text { dengan } \\
\text { harapan } \\
\text { masyarakat } \\
\text { akan } \\
\text { bersimpati } \\
\text { terhadap } \\
\text { perusahaan } \\
\text { dan tidak } \\
\text { menggangg } \\
\text { U aktivitas } \\
\text { perusahaan. } \\
\text { CSR dilaksanaka } \\
\text { n dengan } \\
\text { terpaksa } \\
\text { dan tidak } \\
\text { dengan } \\
\text { sepenuh } \\
\text { hati, karena } \\
\text { perusahaan } \\
\text { harus } \\
\text { mengikuti } \\
\text { peraturan } \\
\text { yang } \\
\text { ditetapkan } \\
\text { oleh } \\
\text { pemerintah. }\end{array}$ \\
\hline Tujuan & $\begin{array}{l}\text { Mencapai } \\
\text { falah di dunia } \\
\text { maupun } \\
\text { akhirat }\end{array}$ & $\begin{array}{l}\text { Mendapat } \\
\text { simpati dari } \\
\text { masyarakat } \\
\text { agar } \\
\text { perusahaan } \\
\text { terus } \\
\text { berkemban } \\
9 \text { ketika } \\
\text { terjadi } \\
\text { permasalah } \\
\text { an sosial. }\end{array}$ \\
\hline $\begin{array}{l}\text { Implemen } \\
\text { tasi dalam }\end{array}$ & $\begin{array}{l}\text { Terdapat } \\
\text { akad dengan }\end{array}$ & $\begin{array}{l}\text { Tidak } \\
\text { terdapat }\end{array}$ \\
\hline
\end{tabular}




\begin{tabular}{|c|c|c|}
\hline $\begin{array}{l}\text { akad } \\
\text { atau } \\
\text { transaksi }\end{array}$ & $\begin{array}{l}\text { niat kebaikan } \\
\text { tanpa } \\
\text { mengharap } \\
\text { keuntungan } \\
\text { secara } \\
\text { ekonomi di } \\
\text { dunia tapi } \\
\text { lebih } \\
\text { mengedepa } \\
\text { nkan } \\
\text { keuntungan } \\
\text { dan benefit } \\
\text { sosial demi } \\
\text { menjaga } \\
\text { keberlangsun } \\
\text { gan generasi } \\
\text { sekarang dan } \\
\text { yang akan } \\
\text { datang, baik } \\
\text { di dunia } \\
\text { maupun di } \\
\text { akhirat. } \\
\end{array}$ & $\begin{array}{l}\text { akad } \\
\text { dengan niat } \\
\text { kebaikan } \\
\text { tanpa } \\
\text { mengharap } \\
\text { kan } \\
\text { keuntungan } \\
\text { secara } \\
\text { ekonomi di } \\
\text { dunia. }\end{array}$ \\
\hline $\begin{array}{l}\text { Sejarah } \\
\text { kemuncul } \\
\text { an }\end{array}$ & $\begin{array}{l}1500 \text { tahun } \\
\text { yang lampau }\end{array}$ & $\begin{array}{l}\text { Akhir abad } \\
\text { ke-19 }\end{array}$ \\
\hline Definisi & $\begin{array}{l}\text { Menjalankan } \\
\text { yang benar } \\
\text { dan } \\
\text { melarang } \\
\text { atau } \\
\text { menentang } \\
\text { yang salah } \\
\text { (Farook, 2007: } \\
\text { 35) }\end{array}$ & $\begin{array}{l}\text { Komitmen } \\
\text { perusahaan } \\
\text { untuk } \\
\text { mengelimin } \\
\text { asi atau } \\
\text { meminimalk } \\
\text { an setiap } \\
\text { efek } \\
\text { berbahaya } \\
\text { (harmful } \\
\text { effects) } \\
\text { dalam } \\
\text { masyarakat } \\
\text { dan } \\
\text { memaksimal } \\
\text { kan } \\
\text { keuntungan } \\
\text { jangka } \\
\text { panjang } \\
\text { (Mohr et.al. } \\
\text { 2001, dalam } \\
\text { Dean, 2004). }\end{array}$ \\
\hline
\end{tabular}

Sumber: Anindya (2011), dimodifikasi oleh peneliti

Dengan demikian, CSR hanya reaksi sosial atau kepedulian perusahaan terhadap dampak negatif dari bisnis ekonomi sekuler yang dilakukan secara serakah dan ekspolitatif. Sedangkan Islamic CSR adalah bentuk tanggung jawab setiap individu yang tergabung dalam sebuah perusahaan terhadap bisnis yang dijalankannya terkait dengan aturan halal dan haram. Dengan kata lain, Islamic CSR adalah CSR yang merujuk kepada praktik bisnis yang memiliki tanggung jawab etis secara Islami, perusahaan memasukkan norma-norma agama Islam yang ditandai oleh adanya komitmen ketulusan dalam menjaga kontrak sosial di dalam praktik bisnisnya (Suharto, 2010: 101).

\section{H. Prinsip Islamic CSR}

Prinsip didefinisikan sebagai dasar, awal, aturan dasar. Menurut Juhaya (1995: 69), prinsip adalah awal yang merupakan titik keberangkatan (almabda). Dalam terminologi, prinsip adalah kebenaran universal yang secara alami ada dalam hukum Islam dan titik awal pembangunannya. Ini adalah bentuk hukum dasar dan menghasilkan semua cabang (Juhaya, 1995). Hal ini dapat disimpulkan bahwa prinsip adalah dasar atau fundamental yang digunakan untuk melandasi praktek kerja.

Pelaksanaan Islamic CSR dapat dikategorikan ke dalam tiga dimensi tanggung jawab hubungan. Pertama, adalah hubungan tanggung jawab kepada Allah. Kedua, hubungan tanggung jawab kepada manusia. Dan yang terakhir adalah hubungan tanggung jawab terhadap lingkungan (Yusuf dan Bahari, 2011). Pelaksanaan Islamic CSR adalah perwujudan dari tiga hubungan 
yang kuat dan saling terkait antara satu sama lain, hubungan dengan Allah, hubungan dengan manusia dan hubungan dengan alam. Untuk mengoptimalkan ketiga hubungan dalam pelaksanaan Islamic CSR, haruslah dipandu dengan prinsip-prinsip keesaan Allah, khalifah, keadilan, solidaritas atau persaudaraan. Keempat prinsip ini ditujukan untuk mewujudkan prinsip kelima yaitu penciptaan maslahah (manfaat publik) bagi manusia dan alam. Menciptakan maslahah pada perusahaan adalah tujuan utama dalam melaksanakan semua aktivitas binis termasuk pelaksanaan CSR Islam. Oleh karena itu, semua pelaksanaan CSR dalam perusahaan harus dipandu oleh aturan halal yang digariskan oleh Islam dan meninggalkan larangan apapun yang dicegah dalam Islam. Semua prinsip ini dipraktekkan dengan satu tujuan yaitu pengabdian yang sempurna kepada Allah SWT. Semua prinsip ini dipraktekkan dengan satu tujuan yaitu pengabdian yang sempurna kepada Allah SWT. Prinsipprinsip diatas akan dijelaskan secara singkat di bawah ini:

1. Keesaan (Tauhid)

Manusia menurut fitrahnya adalah beragama tauhid. Manusia diciptakan Allah mempunyai naluri beragama, yaitu agama tauhid yang dengan firman Allah dalam QS Ar-Ruum [30] ayat 30.

Percaya hanya kepada satu tuhan, yaitu Allah Swt, adalah tujuan dari syariah (Mohammed, 2007). Dalam Islam, kepercayaan atau iman adalah penting untuk kesejahteraan manusia (falah). Iman kepada Allah memberikan pondasi yang tepat bagi hubungan dengan orang lain, yang memungkinkan manusia bertindak dengan cara menghormati dan peduli. Iman kepada Allah juga memberikan filter moral, yang diperlukan dalam alokasi dan distribusi sumber daya berdasarkan persaudaraan dan keadilan sosial-ekonomi. Selanjutnya, iman dalam Islam adalah motivasi untuk pemenuhan kebutuhan dan distribusi kekayaan yang adil (Chapra, 1992).

2. Kekhalifahan

Chapra (1992) mengatakan bahwa prinsip kekhalifahan diturunkan langsung dari prinsip keesaan (tauhid) yang menjelaskan tujuan dan perilaku manusia untuk mengatur tanggung jawab sosial dan keadilan sebagai bagian dari kepercayaan (iman). Selain menjadi hamba yang taat kepada Allah SWT, manusia juga dituntut untuk melakukan ibadah umum lainnya, semua kegiatan yang membawa kesejahteraan dan mengembangkan potensi manusia dan alam sesuai dengan kondisi tertentu, dengan niat yang benar dan harus memastikan bahwa tindakan-tindakan diizinkan oleh aturan syariah.

Al Mawdudi menafsirkan arti kata "khalifah" sebagai "wakil Allah di bumi" (Al Mawdudi, 1967: 16-23). Sebagai khalifah, manusia diberi kepercayaan untuk mengelola lingkungan ini melibatkan hubungan manusia dengan sesama manusia dan hubungan manusia dengan ciptaan Allah, termasuk hewan, 
tumbuhan dan lingkungan. Diantara semua makhluk ciptaan Allah manusia lah yang paling tinggi derajatnya, oleh karena itu manusia dipilih Allah untuk mejadi pemimpin di muka bumi, hal ini sesuai dengan firman Allah dalam QS AlAn'am [6] ayat 165.

3. Keadilan

Salim (1994) menyatakan bahwa al-Adl bermakna al-inshaf wa al-sawiyyat artinya: berada di pertengahan dan mempersamakan. Secara etimologis aladl bermakna al-istiwa (keadaan lurus) juga bermakna: jujur, adil, seimbang, sama, sesuai, sederhana, dan moderat (Asse, 2010)

Allah telah menciptakan segala sesuatu dengan sempurna dan seimbang sebagaimana firman-Nya dalam QS AlMulk [67] ayat 3 dan 4. Semua ini mungkin bagi Allah karena Allah Maha Kuasa dan dengan sempurna dapat melaksanakan kehendak dan tujuan-Nya, yaitu cinta, kasih dan kebaikan kepada makhluk-Nya. Sebagai khalifah, manusia seharusnya menerapkan sifat-sifat ini dan memenuhi kewajibannya melalui tanggung jawab sosial dan keadilan dalam rangka menjaga keseimbangan dalam masyarakat, Mohammed (2007). Perintah Allah kepada manusia untuk berlaku adil tertuang dalam QS An-Nisaa' [4] ayat 58 dimana Allah SWT memerintahkan manusia berlaku adil apabila menetapkan hukum di antara manusia, apabila seseorang menetapkan hukum di antara mereka dengan tidak adil, maka kehidupan masyarakat menjadi pincang, dan akan terjadi diskriminasi.

4. Persaudaraan

Persaudaraan dalam Islam biasa disebut "ukhuwah" yang berarti "memperhatikan", perhatian tersebut muncul karena adanya persamaan di antara pihak-pihak yang bersaudara, sehingga makna tersebut kemudian berkembang, dan pada akhirnya ukhuwah diartikan sebagai "setiap persamaan dan keserasian dengan pihak lain, baik persamaan keturunan, dari segi ibu, bapak, atau keduanya, maupun dari segi persusuan (Shihab, 1996: 477).

Islam menekankan pentingnya membangun hubungan persaudaraan antara sesama muslim. Persaudaraan yang dimaksud bukanlah menurut ikatan geneologi tapi menurut ikatan iman dan agama. Banyak nash, baik dalam AlQuran maupun al-Hadits, yang menegaskan bahwa sesama muslim itu bersaudara sebagaimana firman Allah SWT dalam surat Al-Hujuraat [49] ayat 10.

\section{Kriteria dan instrumen Islamic CSR}

Untuk

mengoptimalkan

implementasi Islamic CSR berdasarkan keempat prinsip diatas, Yusuf dan Bahari (2011) menyebutkan enam kriteria dan 32 instrumen guna mengukur tanggung jawab sosial Islam dalam perusahaan. Enam kriteria dan 32 instrumen dalam Islamic CSR tersebut tersaji pada tabel 2 berikut: 
Tabel 2:

Tabel Instrumen dan Kriteria dalam Implementasi Islamic CSR

\begin{tabular}{|c|c|c|}
\hline Kriteria & Item & Prinsip CSR Islam \\
\hline \multirow{4}{*}{$\begin{array}{l}\text { 1. Syariah } \\
\text { Complian } \\
\text { ce } \\
\text { QS 4: } 59 \text {, } \\
\text { QS 23: } 5\end{array}$} & $\begin{array}{l}\text { 1. Akad yang sesuai } \\
\text { dengan koridor syariah } \\
\text { (DSN) }\end{array}$ & Keesaan \\
\hline & $\begin{array}{l}2 . \\
\text { perusahaan yang halal }\end{array}$ & $\begin{array}{l}\text { Keesaan, kekalifahan, } \\
\text { keadilan }\end{array}$ \\
\hline & $\begin{array}{l}\text { 3. Investasi dalam sektor } \\
\text { halal }\end{array}$ & Keesaan, kekalifahan \\
\hline & $\begin{array}{l}\text { 4. Menghindari laba non- } \\
\text { halal }\end{array}$ & $\begin{array}{l}\text { Keesaan, kekalifahan, } \\
\text { keadilan }\end{array}$ \\
\hline \multirow{4}{*}{$\begin{array}{l}2 . \\
\text { Kesetaraa } \\
\text { n } \\
\text { QS 3: 103, } \\
\text { QS 49: 13. }\end{array}$} & $\begin{array}{l}\text { 1. Adanya nilai-nilai } \\
\text { persaudaraan }\end{array}$ & Persaudaraan, keadilan \\
\hline & 2. Pelayanan yang baik & Persaudaraan, keadilan \\
\hline & 3. Menghindari diskriminasi & Keadilan \\
\hline & $\begin{array}{l}\text { 4. Memiliki kesempatan } \\
\text { yang sama }\end{array}$ & $\begin{array}{l}\text { Persaudaraan, keadilan, } \\
\text { penciptaan maslahah }\end{array}$ \\
\hline \multirow{9}{*}{$\begin{array}{l}3 . \\
\text { Tanggung } \\
\text { jawab } \\
\text { dalam } \\
\text { bekerja } \\
\text { QS 17: } 36\end{array}$} & 1. Kepercayaan & Keesaan \\
\hline & $\begin{array}{l}\text { 2. Bekerja sesuai dengan } \\
\text { batasan dan tanggung } \\
\text { jawab }\end{array}$ & Keadilan \\
\hline & $\begin{array}{l}\text { 3. Memenuhi setiap } \\
\text { permintaan kontrak }\end{array}$ & Keadilan \\
\hline & 4. Transparansi & Keesaan \\
\hline & $\begin{array}{l}\text { 5. Optimal dalam } \\
\text { menggunakan waktu dan } \\
\text { kemampuan }\end{array}$ & $\begin{array}{l}\text { Keesaan, penciptaan } \\
\text { maslahah }\end{array}$ \\
\hline & $\begin{array}{l}\text { 6. Mengurangi dampak } \\
\text { negatif dari investasi }\end{array}$ & $\begin{array}{l}\text { Keeasaan, penciptaan } \\
\text { maslahah }\end{array}$ \\
\hline & 7. Integritas dalam bekerja & Keesaan, keadilan \\
\hline & 8. Persaingan yang adil & $\begin{array}{l}\text { Keadilan, penciptaan } \\
\text { maslahah }\end{array}$ \\
\hline & 9. Akuntabilitas & $\begin{array}{lr}\text { Keadilan, } & \text { penciptaan } \\
\text { maslahah, } & \text { persaudaraan }\end{array}$ \\
\hline \multirow{5}{*}{$\begin{array}{l}4 . \\
\text { Jaminan } \\
\text { kesejahter } \\
\text { aan } \\
\text { QS 16:90 }\end{array}$} & $\begin{array}{l}\text { 1. Tempat kerja yang aman } \\
\text { dan nyaman }\end{array}$ & $\begin{array}{l}\text { Kekalifahan, } \\
\text { persaudaraan }\end{array}$ \\
\hline & $\begin{array}{l}\text { 2. Memperoleh hak yang } \\
\text { sesuai }\end{array}$ & Keadilan, persaudaraan \\
\hline & 3. Gaji yang layak & Keadilan, persaudaraan \\
\hline & $\begin{array}{l}4 . \quad \text { Pelatihan } \\
\text { pendidikan }\end{array}$ & Kekalifahan \\
\hline & 5. Tunjangan dan Asuransi & $\begin{array}{l}\text { Keadilan, kekalifahan, } \\
\text { persaudaraan }\end{array}$ \\
\hline \multirow{4}{*}{$\begin{array}{l}5 . \\
\text { Jaminan } \\
\text { kelestaria } \\
n \\
\text { lingkunga } \\
n \\
\text { QS 30: 41, } \\
\text { QS 7: } 56 .\end{array}$} & $\begin{array}{ll}\text { 1. Memastikan investasi } \\
\text { yang tidak } & \text { merusak } \\
\text { lingkungan } & \\
\end{array}$ & Keesaan, kekalifahan \\
\hline & $\begin{array}{l}\text { 2. Terlibat aktif dalam } \\
\text { melindungi lingkungan }\end{array}$ & Keesaan, kekalifahan \\
\hline & $\begin{array}{l}\text { 3. Mendidik karyawan } \\
\text { untuk peduli dan merawat } \\
\text { lingkungan }\end{array}$ & Keesaan, kekalifahan \\
\hline & $\begin{array}{l}\text { 4. Penggunaan bahan } \\
\text { daur ulang } \begin{array}{r}\text { untuk } \\
\text { memenuhi kebutuhan } \\
\text { perusahaan }\end{array} \\
\end{array}$ & $\begin{array}{l}\text { Kekalifahan, penciptaan } \\
\text { maslahah }\end{array}$ \\
\hline \multirow{4}{*}{$\begin{array}{l}\text { 6. Amal } \\
\text { untuk } \\
\text { pelestaria } \\
n \\
\text { kebajikan } \\
\text { QS 57: } 7 \text {, } \\
\text { QS 16: 71, } \\
\text { QS 9:7 }\end{array}$} & $\begin{array}{l}\text { 1. Pemilihan investor untuk } \\
\text { mendukung kegiatan } \\
\text { kesejahteraan sosial }\end{array}$ & $\begin{array}{l}\text { Kekalifahan, penciptaan } \\
\text { maslahah }\end{array}$ \\
\hline & $\begin{array}{l}\text { 2. Mengurangi masalah } \\
\text { sosial }\end{array}$ & $\begin{array}{l}\text { Persaudaraan, } \\
\text { penciptaan maslahah }\end{array}$ \\
\hline & $\begin{array}{l}\text { 3. Mendukung dan } \\
\text { membantu mendanai } \\
\text { kesejahteraan }\end{array}$ & $\begin{array}{l}\text { Persaudaraan, } \\
\text { penciptaan maslahah }\end{array}$ \\
\hline & $\begin{array}{lr}4 . \quad \text { Berperan } & \text { untuk } \\
\text { kesejahteraan bukan untuk } \\
\text { mencari } & \text { keuntungan } \\
\text { semata } & \\
\end{array}$ & $\begin{array}{l}\text { Keesaan, kekhalifahan, } \\
\text { Persaudaraan, } \\
\text { penciptaan maslahah }\end{array}$ \\
\hline
\end{tabular}

Sumber: Yusuf \& Bahari (2011), diolah.

\section{HASIL PENELITIAN DAN PEMBAHASAN}

\section{A. Implementasi Prinsip Keesaan (Tauhid)}

\section{dalam Islamic CSR di PT. Bumi Lingga}

\section{Pertiwi}

Prinsip keesaan (tauhid) dalam implementasi Islamic CSR oleh PT. BLP diterapkan dengan cara setiap perbuatan khususnya kegiatan sosial, dilakukan dalam rangka menjalankan perintah Allah Swt, tanpa mengharap balasan serta tidak ada motif untuk mencari keuntungan. Sementara dalam operasionalnya, menghindari akad kontrak yang mengandung unsur gharar, spekulasi, tidak menetapkan bunga dalam memberikan pinjaman kepada pihak peminjam modal, senantiasa transparan mengenai laporan keuangan hingga kualitas rumah yang dijual kepada konsumen, jujur dan tidak pernah mengumbar janji kepada konsumen. PT. BLP ikut menjaga kelestarian lingkungan dengan cara melakukan tanam pohon bersama dan mendidik karyawannya untuk peduli kepada lingkungan dengan cara membiasakan untuk menanam pohon bersama-sama.

\section{B. Implementasi Prinsip Kekhalifahan} dalam Islamic CSR di PT. Bumi Lingga Pertiwi

Prinsip kekalifahan dalam implementasi Islamic CSR oleh PT. BLP diterapkan dengan cara menciptakan suasana yang aman dan nyaman dengan asas kekeluargaan, mengikutsertakan karyawan dalam pelatihan yang 
diadakan Real Estate Indonesia (REI). Kemudian PT BLP peduli terhadap masa depan umat dengan melakukan tanam pohon serta membantu pembangunan sarana pendidikan dan ibadah agar nantinya dapat digunakan oleh generasi anak CuCu.

\section{Implementasi Prinsip Keadilan dalam} Islamic CSR di PT. Bumi Lingga Pertiwi

Prinsip Keadilan dalam implementasi Islamic CSR oleh PT. BLP diterapkan dengan cara melayani seluruh konsumen dengan baik tanpa membeda-bedakan status, suku, agama, dan ras. Memberikan tunjangan kepada setiap karyawan dengan jumlah yang sama pada setiap jabatan, membiayai kuliah bagi anak karyawan dengan pertimbangan tertentu, memberangkatkan empat orang karyawan setiap tahunnya untuk umroh dengan ketentuan yang telah ditetapkan, memberikan porsi kerja kepada karyawan yang sesuai dengan bagian, kemampuan dan tanggung jawab masing-masing. Penetapan promosi jabatan untuk karyawan berdasarkan pengalaman, keahlian dan kemauan untuk belajar.

\section{Implementasi Prinsip Persaudaraan} dalam Islamic CSR di PT. Bumi Lingga Pertiwi

Prinsip persaudaraan dalam implementasi Islamic CSR oleh PT. Bumi Lingga Pertiwi (PT. BLP) diterapkan dengan cara melayani pelanggan dengan baik, sopan dan ramah, senantiasa menerapkan asas kekeluargaan dan tolong menolong dalam bekerja sehingga tercipta suasana kerja yang nyaman dan tidak membosankan. PT. BLP memberikan reward kepada karyawannya berupa umroh gratis bagi yang berprestasi dan memenuhi ketentuan dalam rangka mendidik dan merangsang mereka dalam bentuk kebaikan agar bekerja dengan baik. Memberikan bantuan berupa beras kepada warga dusun miskin di sekitar serta vang di setiap bulan Muharram. Membantu pembangunan sekolah dan masjid dengan cara menyediakan lahan untuk kemudian didirikan bangunan standar layak pakai dan pembayarannya dapat dicicil tanpa menggunakan bunga serta tanpa ada motif mencari keuntungan, murni untuk kepentingan umat.

\section{KESIMPULAN DAN SARAN}

\section{A. Simpulan}

Berdasarkan analisis dan pembahasan yang telah dijelaskan dalam pembahasan, maka dapat diperoleh simpulan sebagai berikut:

1. PT. Bumi Lingga Pertiwi (PT. BLP) belum mengimplementasikan prinsip keesaan (tauhid) secara sempurna karena masih menggunakan bank konvensional berbasis bunga dalam peminjaman dana atau modal.

2. PT. Bumi Lingga Pertiwi (PT. BLP) belum mengimplementasikan prinsip kekhalifahan secara sempurna karena masih menggunakan bank berbasis bunga dalam peminjaman modal, masih terdapat karyawan yang tidak nyaman dalam bekerja, serta belum tersedianya bahanbahan daur ulang di lingkungan 
kantor sebagai bentuk dukungan lain dalam hal pegembangan dan pemanfaatan potensi alam semesta.

3. PT. Bumi Lingga Pertiwi (PT. BLP) belum mengimplementasikan prinsip keadilan secara sempurna karena masih terdapat karyawan yang merasakan ketidaksesuaian porsi kerja.

4. Prinsip persaudaraan dalam implementasi Islamic CSR oleh PT. Bumi Lingga Pertiwi (PT. BLP) telah diterapkan dengan sempurna yaitu dengan cara melayani pelanggan dengan baik, sopan dan ramah, senantiasa menerapkan asas kekelvargaan dan tolong menolong dalam bekerja sehingga tercipta suasana kerja yang nyaman dan tidak membosankan. PT. BLP memberikan reward kepada karyawannya berupa umroh gratis bagi yang berprestasi dan memenuhi ketentuan dalam rangka mendidik dan merangsang mereka dalam bentuk kebaikan agar bekerja dengan baik. Memberikan bantuan berupa beras kepada warga dusun miskin di sekitar serta vang di setiap bulan Muharram serta membantu pembangunan sekolah dan masjid dengan cara menyediakan lahan untuk kemudian didirikan bangunan standar layak pakai dan pembayarannya dapat dicicil tanpa menggunakan bunga serta tanpa ada motif mencari keuntungan, murni untuk kepentingan umat.

\section{B. Saran}

Saran yang dapat diberikan berdasarkan hasil analisis dalam penelitian ini adalah:

1. PT. Bumi Lingga Pertiwi

PT. Bumi Lingga Pertiwi hendaknya tetap mempertahankan penerapan CSR Islam yang telah dilakukan dalam praktik bisnisnya, serta senantiasa meningkatkan dan mengevaluasi pelaksanaan CSR secara Islami dalam setiap aktivitas atau tindakan apapun, khususnya tindakan yang berkaitan dengan usahanya untuk menghindari timbulnya permasalahanpermasalahan yang disebabkan oleh kurang optimalnya implementasi CSR Islam. PT. BLP hendaknya melakukan peminjaman modal usaha kepada bank syariah yang tidak menggunakan bunga serta lebih terjamin kehalalannya. Oleh karena itu, penerapan Islamic CSR yang baik dan benar selain merupakan bentuk tanggung jawab perusahaan terhadap para pemangku kepentingan (stakeholders), juga sebagai salah satu bentuk usaha untuk mewujudkan kelestarian lingkungan sehingga terciptanya kehidupan yang harmonis, selaras dan seimbang.

2. Bagi Penelitian Selanjutnya

Meneliti tentang penerapan Islamic CSR dengan prinsip baru selain prinsip yang 
telah digunakan dalam penelitian ini, yaitu prinsip penciptaan maslahah yang bertujuan untuk mengetahui tingkatan urgensi dari pelaksanaan CSR Islam, selain itu penggunaan alat ukur atau kriteria yang lebih terfokus. Hasil dari penelitian selanjutnya dapat memberikan sumbangsih kepada perusahaan lainnya baik lembaga keuangan Islam maupun perusahaan umum untuk mempraktekkan konsep Islamic CSR.

\section{DAFTAR PUSTAKA}

Al Tirmizi. 1993. Sunan Al Tirmizi, Kuala Lumpur, Victory Agency.

Alma, Buchari., Donni Juni Priansa. 2009. Manajemen Bisnis Syariah. Penerbit Alfabeta. Bandung.

Al-Mawdudi, Abu al-A'la. 1967. Islamic Way of Life. Delhi: Markazi Maktaba Islami.

Anindya, Tiara.V. 2011. Pengaruh Fungsi Sosial Terhadap Citra Perusahaan dan Istiqomah pada Nasabah Bank Syariah Mandiri di Surabaya. Skripsi Tidak Diterbitkan. Surabaya Fakultas Ekonomi dan Bisnis Universitas Airlangga.

Asse, Ambo. 2010. Konsep Adil dalam AlQur'an. Al- Risalah. Vol. 10 No. 2.

Baron dan P. David. 2006. Business and It's Enviroment. Edisi ke-5. Upper Saddle River, New Jersey: Pearson Education Inc.

Carroll dan B. Archie. 1999. Corporate Social Responsibility. Business and
Society. Chicago. Vol.38, September.

Chapra, M.U. 1992. Islam and the Economic Challenge. Herndon, $\checkmark A$.

Dusuki, Asyraf Wajdi \& Nurdianawati, Irwani Abdullah. 2005. Maqashid al-shari'ah, Maslahah, dan Corporate Social Responsibility. The American Journal of Islamic Social Sciences. Vol. 24 No.1.

Elkington, J. 1997. Cannibals with Forks: The Triple Bottom Line of $2^{1 \text { st }}$ Century Business. Capstone. Oxford

Farook, Sayd. 2007. On corporate social responsibility of Islamic financial institutions. Islamic Economic Studies. Vol. 15 No.1: 32-46

Griffin, W. Ricky, Ebert dan J. Ronald. 1996. Bussiness. Edisi ke-5. Mc Graw Hill.

Juhaya, S. Praja. 1995. Filsafat Hukum Islam, LPPM Unisba, Bandung, Indonesia

Kotler, Philip and Lee, Nancy. 2005. Corporate social responsibility: doing the most good for your company and your cause. New Jersey: John Wiley and Sons, Inc

Malik. 1951. Al-Muwatta. Kairo, Malik, v.2, h.980: 40

Mohammed, J. A. 2007. Corporate social responsibility in Islam. Doctoral dissertation, AUT University

Salim, Abd. Muin. 1994. Fiqh Siyasah Konsepsi Kekuasaan Politik dalam Al-Quran. Jakarta: LSKI

Shihab, M. Quraish. 1996. Wawasan AlQur"an Tafsir Maudhu"i atas 
Pelbagai Persoalan Umat.

Bandung: Mizan.

Steiner A. George dan F. John. 1994.

Business, Goverment and Society: AA managerial Perspective. Edisi ke-7. McGraw-Hill International Edition.

Suharto, Edi. 2010. CSR\&COMDEV Investasi kreatif perusahaan di era globalisasi. Bandung: Alfabeta

Wibisono, Yusuf. 2007. Membedah konsep dan aplikasi CSR. Gresik: Fascho Publishing

Yusuf, Muhammad Y., \& Zakaria Bahari. 2011. Islamic Corporate Social Responsibility in Islamic Banking: Towards Poverty Alleviation. International Conference on Islamic Economics and Finance. vol. 10. 